\title{
Juliana Magdalon
}

\section{Efeitos dos tratamentos com os ácidos oleico ou linoleico in vitro e in vivo sobre a produção de mediadores inflamatórios por macrófagos}

Dissertação apresentada ao Programa de Pós-Graduação em Fisiologia Humana do Instituto de Ciências Biomédicas da Universidade de São Paulo, para obtenção do Título de Mestre em Ciências. 


\section{Juliana Magdalon}

\section{Efeitos dos tratamentos com os ácidos oleico ou linoleico in vitro e in vivo sobre a produção de mediadores inflamatórios por macrófagos}

Dissertação apresentada ao Programa de Pós-Graduação em Fisiologia Humana do Instituto de Ciências Biomédicas da Universidade de São Paulo, para obtenção do Título de Mestre em Ciências.

Área de concentração: Fisiologia Humana Orientador: Rui Duri

Versão Original 


\section{DADOS DE CATALOGAÇÃO NA PUBLICAÇÃO (CIP)}

Serviço de Biblioteca e Informação Biomédica do Instituto de Ciências Biomédicas da Universidade de São Paulo

reprodução não autorizada pelo autor

Magdalon, Juliana.

Efeitos dos tratamentos com os ácidos oleico ou linoleico in vitro ou in vivo sobre a produção de mediadores inflamatórios por macrófagos I Juliana Magdalon. -- São Paulo, 2011.

Orientador: Rui Curi.

Dissertação (Mestrado) - Universidade de São Paulo. Instituto de Ciências Biomédicas. Departamento de Fisiologia e Biofísica. Área de concentração: Fisiologia Humana. Linha de pesquisa: Efeitos dos ácidos graxos em leucócitos.

Versão do título para o inglês: Effects of treatment with oleic or linoleic acids in vitro or in vivo on the production of inflammatory mediators by macrophages

Descritores: 1. Macrófagos 2. Ácidos graxos 3. Espécies reativas de oxigênio 4. Inflamação 5. Citocinas 6. VEGF I. Curi, Rui II. Universidade de São Paulo. Instituto de Ciências Biomédicas. Programa de Pós-Graduação em Fisiologia Humana III. Título. 


\section{UNIVERSIDADE DE SÃO PAULO \\ INSTITUTO DE CIÊNCIAS BIOMÉDICAS}

Candidato(a):

Título da Dissertação:

Orientador(a):
Juliana Magdalon.

Efeitos dos tratamentos com os ácidos oleico ou linoleico in vitro ou in vivo sobre a produção de mediadores inflamatórios por macrófagos.

A Comissão Julgadora dos trabalhos de Defesa da Dissertação de Mestrado, em sessão pública realizada a . $.1 \ldots$ considerou
( ) Aprovado(a)
( ) Reprovado(a)

Examinador(a): Assinatura:

Nome:

Instituição:

Examinador(a): Assinatura:

Nome:

Instituição:

Presidente: Assinatura:

Nome:

Instituição: 


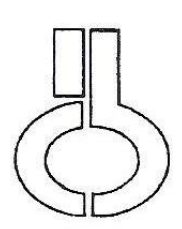

UNIVERSIDADE DE SÃO PAULO

INSTITUTO DE CIÉNCIAS BIOMÉDICAS

Clidade Universitáaria "Armando de Salles Oliveira"

Av. Prof. Lineu Presies, 2415 - CEP. 05508-000 São Paulo, SP - Brasil

Telefone: (55) (011) 3091.7733 - Telefax : (55) (011) 3091.7438

e-mall: cep@icb.usp.b

\section{CERTIFICADO}

Certificamos que o protocolo registrado sob $n^{\circ} 86$ nas fls. 48 do livro 2 para uso de animais em experimentação, sob a responsabilidade de Rui Cusi Coordenador(a) da Linha de pesquisa "Modulação do processo de cicatrizaçäo pelos ácidos oléico e linoleico em netos submetidos ao diabetes meltitus" do qual participou(aram) o(s) alunos Easana Gomes Rodrigues, Muliana Magalaton e a pesquisadora Irlaine Batanalea, está de acordo com os Principios Éticos de Experimentaçāo Animal adotado pelo Colégio Brasileiro de Experimentação Animal (COBEA) e foi aprovado pela COMISSÃO DE ÉTICA EM EXPERIMENTAÇĀO ANIMAL (CEEA) em 31.08.2007.
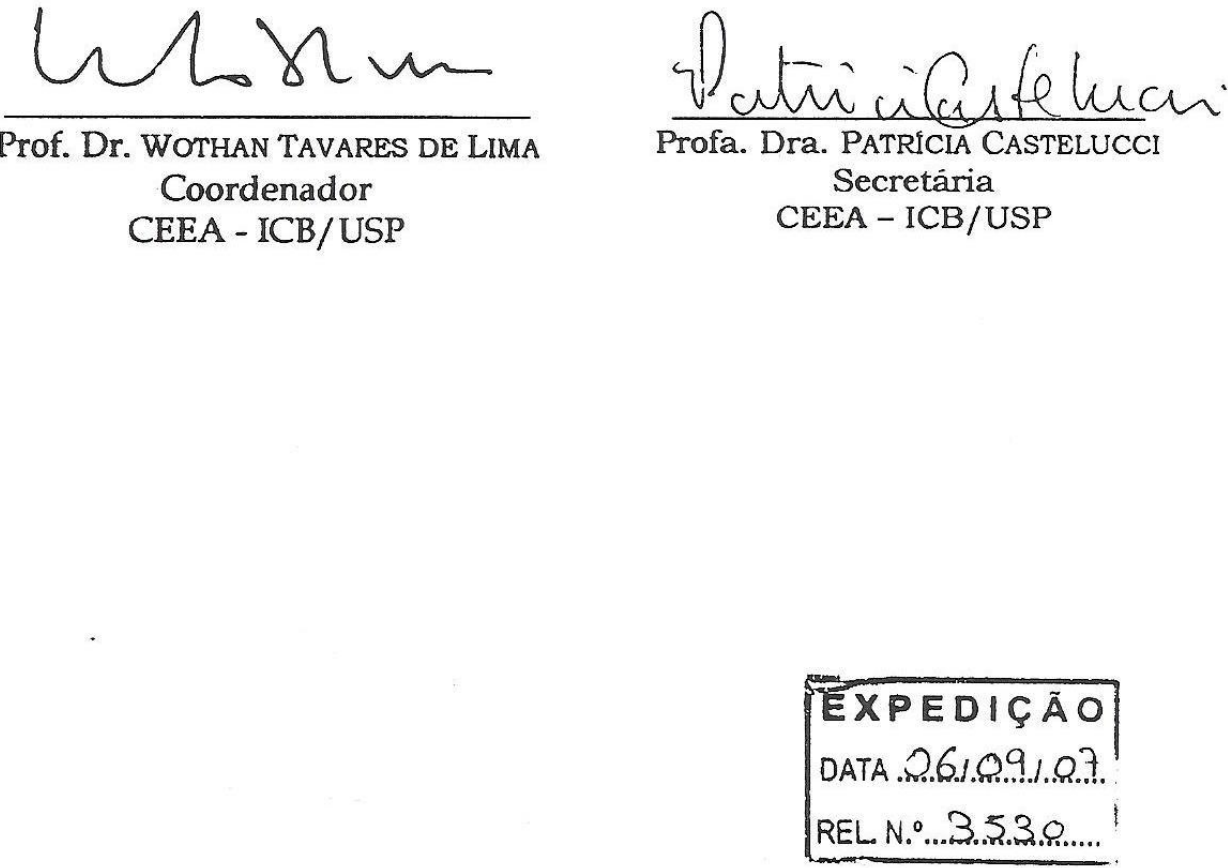


\section{UNIVERSIDADE DE SÃO PAULO}

INSTITUTO DE CIÊNCIAS BIOMÉDICAS

Cidade Universitária "Armando de Salles Oliveira"

Av. Prof. Lineu Prestes, 2415 - cep. 05508-000 São Paulo, SP - Brasil

Telefone :(55) (011) 3091.7733 - telefax : (55) (011) 30917438

e-mail: cep@icb.usp.br

Of.CEUA.51.10

WTL/mcgn

São Paulo, 03 de agosto de 2010.

REF.: Protocolo n086/07.

"Modulação do processo de cicatrização pelos ácidos oléico e linoleico em ratos submetidos ao diabetes mellitus"

Prezado Professor,

Informo que a sua licença para uso de animais em experimentação, constante no protocolo em epígrafe, foi prorrogada até 31.08.2013.

Reitero que havendo alteração de metodologia e inserção de novos alunos ao projeto de pesquisa vinculado à referida licença a CEUAICB deverá ser informada.

Cordialmente,

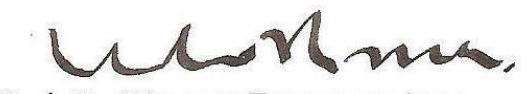

Prof. Dr. WOTHAN TAVARES DE LIMA

Coordenador da Comissão de Ética

no Uso de Animal - ICB /USP

IImo.Sr.

Prof Dr. RUICURI

Departamento de Fisiologia e Biofisica

Instituto de Ciências Biomédicas - USP 
Às pessoas que um dia poderão se beneficiar dos resultados obtidos nesta pesquisa. 


\section{AGRADECIMENTOS}

Ao Prof. Dr. Rui Curi por ter me dado a oportunidade de fazer pesquisa em seu laboratório desde a iniciação científica, por ter me apoiado e acreditado no meu trabalho. Obrigada por tudo que pude aprender nesses últimos anos.

Aos meus co-orientadores Marco Aurélio Ramirez Vinolo e Hosana Gomes Rodrigues por toda a ajuda que sempre me deram. Obrigada pela disposição e pela paciência de tirar minhas infindáveis dúvidas. Agradeço também pelas ideias e realizações dos experimentos, discussões de resultados e correções da qualificação e da dissertação.

À Elaine por tudo que me ensinou e contribuiu para minha formação acadêmica.

Aos colegas do laboratório por proporcionarem um ambiente agradável e divertido de se trabalhar e por estarem sempre dispostos a ajudar no que for preciso.

Aos funcionários do ICB pelo profissionalismo, facilitando o bom desempenho das pesquisas realizadas no instituto.

Ao Bob por todo o auxílio na hora de realizar os experimentos.

À Vivian e à Laiali por compartilharem as dificuldades do mestrado e assim tornarem essa fase mais fácil. Obrigada também pelas distrações e risadas no meio de um dia cansativo de trabalho.

Aos meus pais por terem me possibilitado chegar onde estou. Obrigada por terem se preocupado desde minha infância com minha formação e educação de qualidade. Obrigada por me encorajarem a sempre fazer meu melhor e ainda assim valorizarem meu descanso. E obrigada também pelo apoio financeiro e pelas comidinhas prontas, pois assim tive muito mais tempo disponível para o mestrado.

Aos meus avós, tias e irmão pelo apoio e incentivo. Obrigada pelas preocupações e por acreditarem e torcerem por mim. 
Ao meu namorado Binho, que tanto me ensina e me faz ser uma pessoa melhor em todos os aspectos, inclusive no que se refere à ciência. Agradeço pelo suporte emocional diário que, mesmo após dias exaustivos de trabalho, é dado com muita paciência e carinho. Obrigada por eu sempre poder contar com você e por você me ajudar a tomar as melhores decisões, mesmo que isso signifique você aprender um pouco mais sobre minha área de pesquisa.

Às agências FAPESP, CNPq e CAPES por financiarem a pesquisa de nosso laboratório. 


\section{"A alegria da descoberta é certamente a mais vívida que a mente de um homem jamais poderá sentir."}

Claude Bernard 


\section{RESUMO}

Magdalon J. Efeitos dos tratamentos com os ácidos oleico ou linoleico in vitro e in vivo sobre a produção de mediadores inflamatórios por macrófagos. [dissertação]. São Paulo: Instituto de Ciências Biomédicas da Universidade de São Paulo; 2011.

Macrófagos são essenciais para o início e resolução da inflamação. Para que esses processos sejam ordenados, a síntese de mediadores inflamatórios é estritamente regulada. Os ácidos graxos mais consumidos são os ácidos oleico e linoleico. Ácidos graxos alteram a função imune, porém os efeitos dos ácidos oleico e linoleico sobre a produção de mediadores inflamatórios por macrófagos são desconhecidos. Assim, este estudo teve como objetivo investigar esses efeitos comparando o tratamento in vivo com o in vitro. Foram utilizados macrófagos residentes coletados a partir de lavagem peritoneal de ratos. Para os experimentos com tratamento in vitro, as células foram tratadas com $25 \mu \mathrm{M}, 50 \mu \mathrm{M}$ e $100 \mu \mathrm{M}$ dos ácidos graxos. Para aqueles com tratamento in vivo, os animais foram suplementados por 10 dias com 0,15 g/kg de peso corporal de água (controle), ácidos oleico ou linoleico puros. Inicialmente, foram analisadas fragmentação de DNA (citometria de fluxo) e atividade da succinato desidrogenase mitocondrial (ensaio de MTT) com o intuito de determinar a toxicidade dos ácidos oleico ou linoleico administrados in vitro ou in vivo. Ambos os testes sugeriram que os ácidos graxos não foram tóxicos nas doses utilizadas. Posteriormente, foram realizados os seguintes experimentos: ensaio de quimiluminescência amplificada por lucigenina e ensaio de fluorescência utilizando Amplex ${ }^{\circledR}$ Ultrared para quantificar ROS; ensaio utilizando reagente de Griess e ELISA para quantificar nitrito e citocinas, respectivamente, do sobrenadante de culturas celulares. Somente o tratamento in vitro com os ácidos oleico ou linoleico na ausência de PMA reduziu a produção de ROS, de acordo com o ensaio utilizando Amplex ${ }^{\circledR}$ Ultrared. O tratamento in vitro com ácidos oleico ou linoleico, na ausência ou presença de LPS, inibiu a produção de nitrito, enquanto que o tratamento in vivo com os mesmos ácidos graxos não alterou esta produção. A produção de TNF- $\alpha$ foi reduzida pelo tratamento in vitro com os ácidos oleico ou linoleico na presença de LPS, enquanto que foi reduzida pelo tratamento in vivo com os mesmos ácidos graxos na ausência de LPS. A secreção de IL-1 $\beta$ não foi alterada pelo tratamento in 
vitro, porém foi reduzida pelo tratamento in vivo com ácidos oleico ou linoleico na ausência de LPS. A síntese de IL-6 foi aumentada somente pelas células tratadas in vitro com ácido oleico, na ausência ou presença de LPS, e foi inibida pelos macrófagos dos animais tratados com ácidos oleico ou linoleico, na ausência de LPS. A produção de CINC-2 $\alpha \beta$ foi aumentada pelo tratamento in vitro com ácidos oleico ou linoleico na ausência de LPS, mas foi reduzida pelo tratamento in vivo com os mesmos ácidos graxos também na ausência de LPS. Já a produção de VEGF foi maior nas células tratadas in vitro com ácidos oleico ou linoleico, porém menor naquelas dos animais tratados com ácido linoleico. No geral, o tratamento in vitro com ácidos oleico ou linoleico apresentou efeitos pró-inflamatórios, enquanto que o tratamento in vivo com os mesmos ácidos graxos provocou efeitos anti-inflamatórios, sugerindo que os ácidos oleico e linoleico podem ser usados como agentes terapêuticos.

Palavras-chaves: Macrófagos. Ácidos graxos. Espécies reativas de oxigênio. Inflamação. Citocinas. VEGF. 


\begin{abstract}
Magdalon J. Effects of treatment with oleic or linoleic acids in vitro or in vivo on the production of inflammatory mediators by macrophages [Masters thesis]. São Paulo: Instituto de Ciências Biomédicas da Universidade de São Paulo; 2011.
\end{abstract}

Macrophages play a central role in the beginning and resolution of inflammation. In order for these processes to be organized, the synthesis of inflammatory mediators is strictly regulated. The most consumed fatty acids are oleic and linoleic acids. Fatty acids alter immune function, but the effects of oleic and linoleic acids on the production of inflammatory mediators by macrophages are unknown. Therefore, this study aimed to investigate these effects comparing in vivo and in vitro treatments. Resident macrophages were used and harvested by rat peritoneal lavage. For experiments using in vitro treatment, cells were treated with $25 \mu \mathrm{M}, 50 \mu \mathrm{M}$ and 100 $\mu \mathrm{M}$ of fatty acids. For those using in vivo treatment, animals were supplemented for 10 days with $0.15 \mathrm{~g} / \mathrm{kg}$ body weight of water (control), pure oleic or linoleic acids. Initially, DNA fragmentation (flow citometry) and mitochondrial succinate dehydrogenase activity were measured in order to evaluate the citotoxicity of oleic and linoleic acid when administered in vitro or in vivo. Both tests suggested that the fatty acids were not toxic at the doses used. Subsequently, the following assays were performed: lucigenin-amplified chemiluminescence and Amplex ${ }^{\circledR}$ Ultrared fuorescence for measuring ROS; Griess reagent and ELISA for measuring nitrite and cytokines, respectively, from cell culture supernatants. In vitro treatment with oleic or linoleic acids without PMA was the only one to decrease ROS production, according to $A m p l e x{ }^{\circledR}$ Ultrared assay. In vitro treatment with oleic or linoleic acids with or without LPS inhibited nitrite production, whereas in vivo treatment with the same fatty acids has not altered this production. TNF- $\alpha$ production was decreased by in vitro treatment with oleic or linoleic acids in the presence of LPS, whereas it was decreased by in vivo treatment with the same fatty acids in the absence of LPS. IL-1 $\beta$ release was not altered by in vitro treatment, however, it was decreased by in vivo treatment with oleic or linoleic acids without LPS. IL-6 synthesis was augmented in cells treated in vitro with oleic acid, with or without LPS, and it was inhibited in macrophages from animals treated with oleic or linoleic acids, in the absence of LPS. 
CINC-2 $\alpha \beta$ production was increased by in vitro treatment with oleic or linoleic acids without LPS, but it was decreased by in vivo treatment with the same fatty acids also without LPS. VEGF production was greater in cells treated in vitro with oleic or linoleic acids, but lower in those from animals treated with linoleic acid. Overall, in vitro treatment with oleic or linoleic acids presented pro-inflammatory effects, whereas in vivo treatment with the same fatty acids caused anti-inflammatory effects, suggesting that oleic and linoleic acids may be used as therapeutic agents.

Keywords: Macrophages. Fatty acids. Reactive oxygen species. Inflammation. Cytokines. VEGF. 


\section{LISTA DE ILUSTRAÇÕES}

Figura 1. Metabolismo de ácidos graxos

Figura 2. Ensaio de MTT em macrófagos tratados in vitro e in vivo com os ácidos oleico ou linoleico.

Figura 3. Fragmentação de DNA em macrófagos tratados in vitro e in vivo com os ácidos oleico ou linoleico

Figura 4. Produção de ânion superóxido durante $1 \mathrm{~h}$ por macrófagos tratados in vitro com os ácidos oleico ou linoleico.

Figura 5. Produção de ânion superóxido durante $1 \mathrm{~h}$ por macrófagos tratados in vivo com os ácidos oleico ou linoleico. .41

Figura 6. Produção de peróxido de hidrogênio durante $1 \mathrm{~h}$ por macrófagos tratados in vitro com os ácidos oleico ou linoleico. .42

Figura 7. Produção de peróxido de hidrogênio durante $1 \mathrm{~h}$ por macrófagos tratados in vivo com os ácidos oleico ou linoleico

Figura 8. Produção de nitrito durante $24 \mathrm{~h}$ por macrófagos tratados in vitro com os ácidos oleico ou linoleico

Figura 9. Produção de nitrito durante $24 \mathrm{~h}$ por macrófagos tratados in vivo com os ácidos oleico ou linoleico

Figura 10. Produção de TNF- $\alpha$ durante $24 \mathrm{~h}$ por macrófagos tratados in vitro com os ácidos oleico ou linoleico.

Figura 11. Produção de TNF-a durante 5 e $24 \mathrm{~h}$ por macrófagos tratados in vivo com os ácidos oleico ou linoleico.

Figura 12. Produção de IL-1 $\beta$ durante $24 \mathrm{~h}$ por macrófagos tratados in vitro com os ácidos oleico ou linoleico. 
Figura 13. Produção de IL-1 $\beta$ durante 5 e $24 \mathrm{~h}$ por macrófagos tratados in vivo com os ácidos oleico ou linoleico.

Figura 14. Produção de IL-6 durante 24 h por macrófagos tratados in vitro com os ácidos oleico ou linoleico

Figura 15. Produção de IL-6 durante 5 e 24 h por macrófagos tratados in vivo com os ácidos oleico ou linoleico.

Figura 16. Produção de CINC-2 $\alpha \beta$ durante $24 \mathrm{~h}$ por macrófagos tratados in vitro com os ácidos oleico ou linoleico.

Figura 17. Produção de CINC-2 $\alpha \beta$ durante 5 e 24 h por macrófagos tratados in vivo com os ácidos oleico ou linoleico.

Figura 18. Produção de VEGF durante $24 \mathrm{~h}$ por macrófagos tratados in vitro com os ácidos oleico ou linoleico. .50

Figura 19. Produção de VEGF durante 5 e 24 h por macrófagos tratados in vivo com os ácidos oleico ou linoleico. 


\section{LISTA DE TABELAS}

Tabela 1. Resumo dos efeitos dos tratamentos in vitro e in vivo com os ácidos oleico ou linoleico .51 


\section{LISTA DE ABREVIATURAS E SIGLAS}

ANOVA: análise de variância

AP-1: proteína ativadora 1

C/EBP $\beta$ : proteína ligante ao amplificador CCAAT $\beta$

CINC-2 $\alpha \beta$ : citocina indutora da quimiotaxia de neutrófilos $2 \alpha$ e $\beta$

CLR: receptor de lectina tipo C

COX-2: ciclo-oxigenase 2

DAMP: padrão molecular associado a danos

DC: célula dendrítica

DHA: ácido docosaexaenoico

EGF: fator de crescimento epidermal

EPA: ácido eicosapentaenoico

HDL: lipoproteína de densidade alta

HRP: peroxidase de raiz forte

IDL: lipoproteína de densidade intermediária

IFN-Y: interferon- $\mathrm{Y}$

IL: interleucina

IL-1ra: antagonista do receptor de IL-1

iNOS: óxido nítrico sintase induzível

IRF: fator regulador de IFN

LDL: lipoproteína de densidade baixa

LPL: lipase de lipoproteína

LPS: lipopolissacarídeo

MCP-1: proteína quimioatraente de monócitos 1 
MNC: célula mononucleares

MTT: brometo de 3-(4,5-dimetil-2-tiazolil)-2,5-difenil-2H-tetrazólio

MUFA: ácido graxo monoinsaturado

NF-kB: fator nuclear kappa B

NO: óxido nítrico

NRL: receptor do tipo NOD

PAMP: padrão molecular associado a patógenos

PG: prostaglandina

PMA: acetato miristato de forbol

PMN: célula polimorfonuclear

PPAR: receptor nuclear ativador da proliferação de peroxissomos

PRR: receptor de reconhecimento de padrões moleculares

PUFA: ácido graxo poli-insaturado

RLR: receptor do tipo RIG-I

ROS: espécies reativas de oxigênio

RNS: espécies reativas de nitrogênio

EPM: erro padrão da média

SFB: soro fetal bovino

TGF- $\beta$ : fator de crescimento transformante $\beta$

TLR: receptor do tipo Toll

TNF- $\alpha$ : fator de necrose tumoral $\alpha$

VCAM1: molécula de adesão de célula vascular 1

VEGF: fator de crescimento endotelial vascular

VLDL: lipoproteína de densidade muito baixa 


\section{SUMÁRIO}

1 INTRODUÇÃO

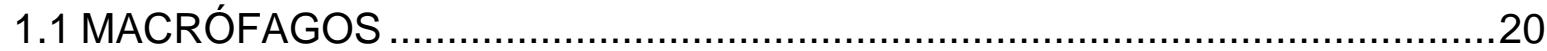

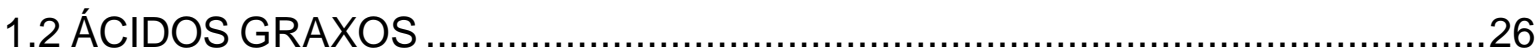

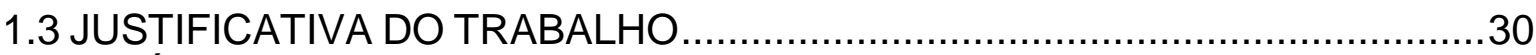

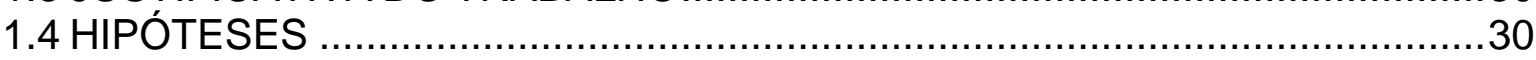

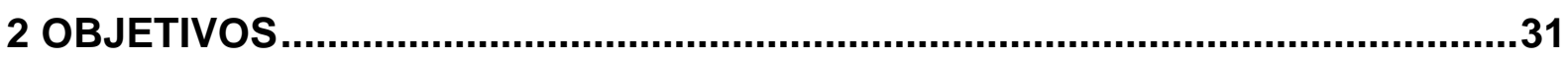

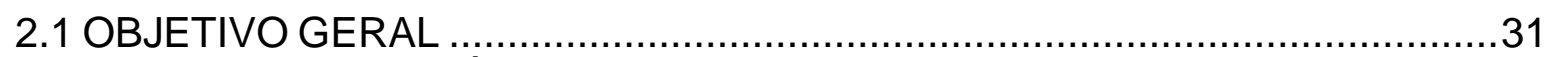

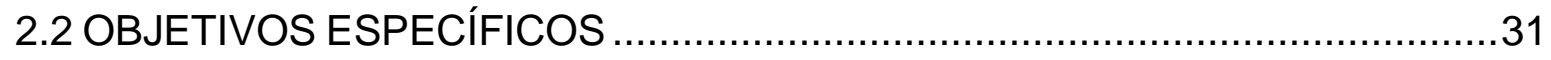

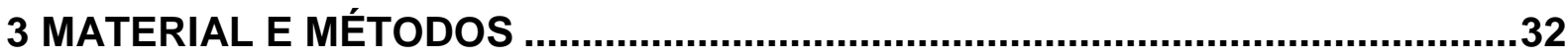

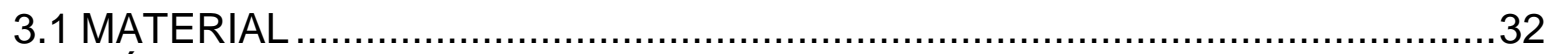

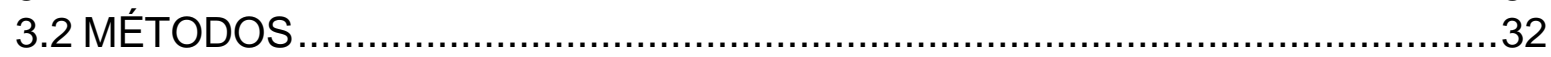

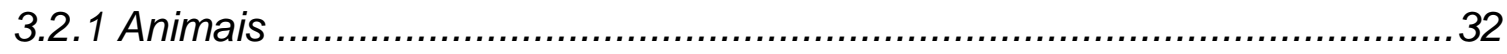

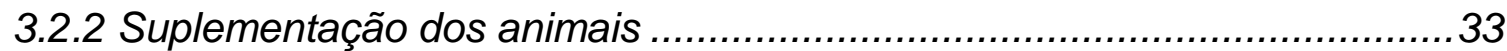

3.2.3 Separação e cultura de células peritoneais de ratos ..................................33

3.2.4 Tratamento in vitro das células ..........................................................34

3.2.5 Análise de citotoxicidade por citometria de fluxo.....................................34

3.2.6 Análise de citotoxicidade por ensaio de MTT ..........................................35

3.2.7 Ensaio de quimiluminescência amplificada por lucigenina ..........................35

3.2.8 Ensaio de fluorescência utilizando Amplex ${ }^{\circledR}$ Ultrared.................................36

3.2.9 Quantificação de citocinas e VEGF no sobrenadante da cultura de

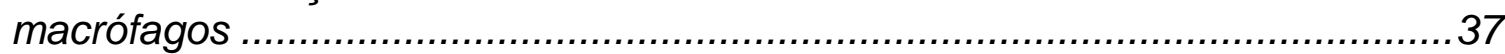

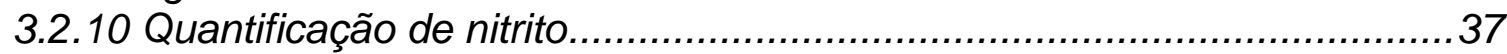

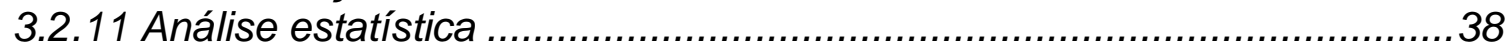

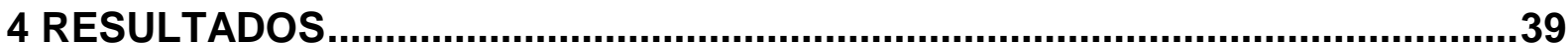

4.1 TOXICIDADE DOS ÁCIDOS GRAXOS EM MACRÓFAGOS .........................39

4.2 EFEITO DOS ÁCIDOS OLEICO E LINOLEICO NA PRODUÇÃO DE ROS ......40

4.3 EFEITO DOS ÁCIDOS OLEICO E LINOLEICO NA PRODUÇÃO DE NITRITO43 4.4 EFEITO DOS ÁCIDOS OLEICO E LINOLEICO NA PRODUÇÃO DE

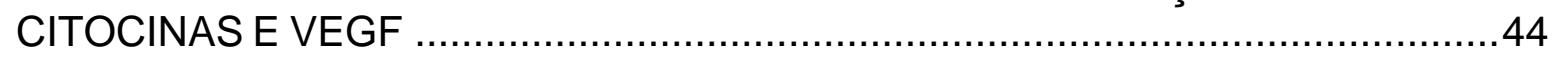

5 DISCUSSÃO

6 CONCLUSÃO

REFERÊNCIAS.............................................ERRO! INDICADOR NÃO DEFINIDO. 


\section{INTRODUÇÃO}

\subsection{MACRÓFAGOS}

O sistema imunológico compreende interações complexas entre órgãos, tecidos, células e moléculas e pode ser dividido nos seguintes mecanismos de defesa: barreiras físicas (pele, membranas das mucosas, epitélio ciliado), barreiras químicas (enzimas presentes em secreções e ácidos estomacais) e leucócitos, que são as células de defesa do organismo. O sistema imunológico também pode ser dividido em resposta imune inata e adaptativa. A resposta imune inata é a primeira linha de defesa do organismo e é caracterizada pela sua rápida cinética e identificação limitada de patógenos. Dentre as células participantes desta resposta, temos: monócitos, macrófagos, DCs e neutrófilos, que reconhecem estruturas moleculares expressas por diferentes classes de patógenos (PAMPs) e posteriormente fagocitam e destroem tais micro-organismos. Já a resposta imune adaptativa é mais sofisticada, já que inclui os receptores de linfócitos $T$ e os anticorpos produzidos por linfócitos $B$, os quais apresentam ampla diversidade $\mathrm{e}$ assim conseguem reconhecer e eliminar um número quase infinito de antígenos. Após a destruição do patógeno, o sistema imune adaptativo estabelece um estado de "memória", possibilitando uma resposta mais rápida e mais vigorosa no caso de um segundo contato com o mesmo agente (1).

A demonstração da presença de fagócitos como parte de uma resposta de defesa do organismo contra "corpos estranhos" foi feita por Metchnikoff em larvas de estrela-do-mar. Este pesquisador, junto com Paul Ehrlich, ganhou o prêmio Nobel de 1908 pelo progresso feito na área de imunidade (2). A função de clearance dos macrófagos foi bastante estudada durante a primeira metade do século 20 e foi seguida por um avanço considerável no estudo sobre a biologia destas células, favorecido pelo desenvolvimento das microscopias de luz e eletrônica (3). Descobertas importantes incluem a identificação do IFN- $\gamma$ como citocina ativadora de macrófagos (4), a função da forma induzível da iNOS nas ações citotóxicas dos macrófagos (5), caracterização de receptores da membrana plasmática que atuam na fagocitose/endocitose (6-8) e PRRs (9). 
Macrófagos são fagócitos mononucleares não proliferativos originados de monócitos do sangue, os quais, após migração para os tecidos, se diferenciam em macrófagos. Na ausência de processos infecciosos e inflamatórios, esta migração ocorre aleatoriamente em uma taxa baixa (10) enquanto que, na resposta inflamatória, tanto o número de monócitos presentes no sangue quanto o de células que deixam a circulação em direção ao foco inflamatório tecidual é aumentado (11). Os monócitos, além de darem origem a macrófagos e DCs inflamatórias, também atuam como células imunes efetoras em infecções, secretando citocinas e fatores microbicidas (12). A origem destas células se dá na medula óssea, tecido no qual as células tronco hematopoiéticas geram progenitores mieloides que, posteriormente, formam os precursores dos macrófagos e DC. Apesar de já ser bem identificada sua diferenciação em DCs, ainda não está muito claro como esses precursores se diferenciam em monócitos e macrófagos. Diferentes tipos de monócitos são então formados e deixam a medula óssea para entrar na circulação sanguínea. Posteriormente, se diferenciam em macrófagos ao entrar nos tecidos (13).

Além dos monócitos e macrófagos, outras células do sistema imune inato também têm grande participação na resposta inflamatória aguda. Esta é induzida por micro-organismos ou danos teciduais e é classicamente caracterizada por cinco sinais e sintomas: edema, rubor, calor, dor e perda de função tecidual. A resposta inflamatória é mais bem caracterizada para casos de infecção. A presença de microoganismos é identificada por macrófagos e mastócitos residentes do tecido, os quais passam a secretar citocinas (TNF- $\alpha$, IL-1 $1 \beta$, IL-6), quimiocinas (IL-8, MCP-1, CINC$2 \alpha \beta$ ), aminas vasoativas (histamina), eicosanoides (prostaglandinas e leucotrienos) e produtos da cascata proteolítica que amplificam a resposta inflamatória. Inicialmente, os vasos sanguíneos locais dilatam, aumentando o fluxo sanguíneo e diminuindo sua velocidade. Além disso, há aumento da permeabilidade vascular e consequente extravasamento de líquido e proteínas plasmáticas para o interstício. Células endoteliais e neutrófilos dos vasos sanguíneos locais passam a expressar moléculas de adesão, possibilitando o rolamento, adesão e diapedese destes leucócitos para o foco inflamatório $(14,15)$.

Os leucócitos que migram e os residentes reconhecem os PAMPs dos agentes infecciosos pelos seus PRRs. São quatro as famílias de PRRs: TLRs, CLRs, RLRs e NLRs. Por exemplo, o LPS, componente derivado da parede celular de 
bactérias gram-negativas, é um PAMP reconhecido pelo TLR4. Os PRRs também são responsáveis por reconhecer moléculas endógenas liberadas durante processo de morte celular (DAMPs). Com exceção de alguns NLRs, a via de sinalização dos PRRs acarreta na ativação e deslocamento de determinados fatores de transcrição para o núcleo, dentre os quais pode-se citar: NF-kB, AP-1, IRFs e C/EBP $\beta$. Assim, esses fatores acabam por ativar a transcrição de genes relacionados à resposta inflamatória, como aqueles que codificam citocinas pró-inflamatórias, quimiocinas, IFNs do tipo I e proteínas microbicidas (16).

Durante a passagem dos neutrófilos pelo endotélio e sua migração para o tecido, há liberação de grânulos intracelulares contendo proteínas microbicidas e capazes de degradar a matriz extracelular. Estas proteínas liberadas são essenciais para o recrutamento de monócitos com fenótipo mais inflamatório, já que, além de induzirem a expressão de quimioatraentes nas células das proximidades, modificam a estrutura de quimiocinas secretadas no tecido, potencializando suas ações. Embora o recrutamento de neutrófilos e monócitos seja similar, há diferenças nas moléculas de adesão expressas pelo endotélio e nas quimiocinas que atraem estas células. A IL-6, secretada por macrófagos residentes e células endoteliais, e seu receptor solúvel sIL-6Ra têm importante função na transição para o recrutamento de monócitos. O IL-6Ra, liberado por neutrófilos ativados por quimioatraentes, se liga à IL-6 e juntos ativam células endoteliais a expressar as quimiocinas IL-8 e MCP-1 e a VCAM1, que desencadeiam a migração e adesão dos monócitos $(15,17)$.

Os neutrófilos e os macrófagos agem então em conjunto para eliminar os patógenos. Assim que o micro-organismo é fagocitado, os lisossomos e outros grânulos citoplasmáticos entram em contato com o fagossomo, liberando vários agentes microbicidas como lisozimas, proteínas antimicrobianas, ROS e RNS. ROS e RNS têm outras funções na resposta inflamatória além de efeitos microbicidas. Em baixas concentrações, são importantes na sinalização de uma variedade de processos celulares, incluindo transdução de sinal, proliferação, diferenciação, migração, senescência e apoptose. Porém, em altas concentrações, superam o sistema de defesa antioxidante do organismo, resultando em danos celulares nos próprios tecidos do organismo (18-20). 
A produção de ROS é catalisada pelo complexo NADPH oxidase, localizado na membrana plasmática ou nas membranas de fagossomos. No estado inativo, 0 complexo possui dois elementos transmembrânicos (gp91 ${ }^{\mathrm{PHOX}}, \mathrm{p} 22^{\mathrm{PHOX}}$ ) e três componentes citossólicos ( $\mathrm{p} 67^{\mathrm{PHOX}}, \mathrm{p} 47^{\mathrm{PHOX}}, \mathrm{p} 40^{\mathrm{PHOX}}$ ). Sob ação de alguns estímulos ativadores do sistema NADPH oxidase, há fosforilação de proteínas citoplasmáticas, como a proteína $\mathrm{p} 47^{\mathrm{PHOX}}$, e translocação das mesmas para a membrana citoplasmática, onde juntamente com os componentes da membrana, formam o complexo NADPH oxidase ativo. Este então transfere elétrons do NADPH, localizado no citossol, para o oxigênio, no espaço extracelular ou no lúmen de alguma vesícula, formando o ânion superóxido. Em seguida, este pode desmutar espontaneamente em peróxido de hidrogênio e ambos podem ser posteriormente convertidos a metabólitos mais reativos como radical hidroxila ou ácido hipocloroso $(\mathrm{HOCl})$. A produção de $\mathrm{HOCl}$ é catalisada pela mieloperoxidase, enzima presente principalmente em neutrófilos $(21,22)$. A sinalização celular desencadeada por ROS é promovida principalmente pelo superóxido e o peróxido de hidrogênio. O superóxido age como oxidante apenas em sua forma protonada, mas como somente uma pequena fração do superóxido é protonada em pH fisiológico, sua principal ação é de redutor: ele reduz ferro e reage com centros de sulfeto de ferro. Já o peróxido de hidrogênio reage com domínios tióis de resíduos de cisteína, gerando diversos estados de oxidação do enxofre, como dissulfetos e produtos dos ácidos sulfênico, sulfínico e sulfônico (23).

As RNS são derivadas da reação de NO com outros compostos. A produção de NO em macrófagos é catalisada principalmente pela iNOS, após ativação por citocinas ou produtos bacterianos (20). A baixa concentração de NO inicial é seguida por um aumento em sua produção devido à ativação do NF-kB, que promove a síntese de novo de iNOS. Quando a concentração de NO se eleva, a expressão de iNOS é reduzida, evitando uma superprodução de NO $(24,25)$. A via bioquímica tem como precursor o aminoácido L-arginina que, após duas reações mono-oxigenases (inserção de um átomo de oxigênio em substrato orgânico), forma uma molécula de NO e uma de L-citrulina. Assim, um dos fatores que determina a atividade da iNOS é justamente a disponibilidade extracelular de arginina, a qual é modulada pela arginase. Esta enzima degrada arginina a ureia e ornitina e sua síntese é aumentada em macrófagos após exposição a IL-4, TGF- $\beta$, LPS ou dexametasona (20). A ação 
do NO não é restrita ao local de produção, visto que, por ser um gás, se difunde facilmente pelo organismo. Além disso, ele pode reagir com o oxigênio ou ROS presentes na água, gerando RNS, incluindo compostos estáveis como nitrito e nitrato, e instáveis como peroxinitrito, sendo este um potente oxidante. Os efeitos das RNS no organismo são diversos, visto que elas reagem com DNA (bases pirimidinas), grupos prostéticos (como o grupo heme) e proteínas (levando à Snitrosilação de grupos tióis, nitração de resíduos de tirosina e ruptura de grupos de sulfetos metálicos) $(5,20)$.

Assim que o patógeno é eliminado, a resposta inflamatória precisa ser inibida para evitar danos teciduais excessivos e assim começar a fase de reparo. A sinalização desencadeada pelas células locais inibe a infiltração de mais neutrófilos e estimula a infiltração de monócitos não-inflamatórios e a fagocitose de células apoptóticas por macrófagos, re-estabelecendo a homeostase do tecido (15). Células apoptóticas apresentam modificações na composição da membrana plasmática e são assim reconhecidas por macrófagos. Dentre essas modificações, a mais bem caracterizada é a perda da assimetria dos fosfolipídeos e a translocação de fosfatidilserina para o lado externo da membrana plasmática. Esses novos padrões na superfície das células apoptóticas podem então se ligar diretamente aos receptores de membrana dos macrófagos ou a proteínas séricas, que servem como "ponte" entre o macrófago e a célula em apoptose. Após o reconhecimento, essas células são fagocitadas (26).

Mediadores lipídicos têm uma função essencial neste processo. Aqueles que eram inicialmente sintetizados na resposta inflamatória (prostaglandinas e leucotrienos) são agora substituídos por mediadores que possuem ações antiinflamatórias e que estimulam a resolução da inflamação (lipoxinas, resolvinas e protectinas), ou seja, desencadeiam uma série de sinalizações celulares que acabam por inibir a infiltração de neutrófilos e induzir a fagocitose de células apoptóticas. Para isso, a $\mathrm{PGE}_{2}$ e a $\mathrm{PGD}_{2}$, que possuem atividades pró-inflamatórias, promovem a expressão de enzimas chaves para a síntese dos mediadores da resolução da inflamação. As lipoxinas são derivadas do ácido araquidônico e sua produção é catalisada por lipo-oxigenases. Já as resolvinas são sintetizadas a partir do EPA e do DHA, enquanto que as protectinas são originadas somente a partir do DHA (27). 
Além de remover células potencialmente tóxicas ao tecido, a fagocitose de células apoptóticas estimula os macrófagos a liberarem citocinas e fatores de crescimento importantes para a resolução da inflamação, tais como o TGF- $\beta$ e a IL10 (28, 29). Ao mesmo tempo, o TGF- $\beta$ e a IL-10, junto com os hormônios glicocorticoides produzidos pelo organismo e IL-4 secretada por mastócitos, basófilos e linfócitos Th2, promovem a conversão de macrófagos de um fenótipo pró-inflamatório (M1) para anti-inflamatório (M2). A distinção entre esses dois fenótipos é feita pelos diferentes marcadores da superfície celular, porém ainda não se sabe ao certo se isso reflete vias de diferenciação alternativas dos macrófagos no próprio tecido ou o recrutamento de monócitos com fenótipos já diferentes. Além da secreção de TGF- $\beta$, os macrófagos também contribuem para a resolução da inflamação secretando o VEGF e o EGF, importantes para o remodelamento do tecido e angiogênese (formação de novos vasos sanguíneos). Se o restabelecimento da vasculatura não for apropriado, a quantidade de oxigênio no tecido permanece insuficiente, o que impede o reparo tecidual $(30,31)$.

A não resolução da inflamação, devido à falha em eliminar os patógenos ou produção prolongada de fatores pró-inflamatórios, por exemplo, contribui para o desenvolvimento de diversas patologias, como aterosclerose, obesidade, câncer, asma, doenças inflamatórias intestinais, doenças neurodegenerativas, esclerose múltipla e artrite reumatoide. Nesses casos, a resposta inflamatória deixa de ser aguda e se torna crônica (30). A inflamação crônica pode durar de semanas a anos e apresenta simultaneamente resposta inflamatória, injúria tecidual e cicatrização. Ela é caracterizada pela infiltração de células mononucleares, como macrófagos e linfócitos, que, por produzirem fatores inflamatórios, levam à destruição tecidual. Em alguns casos, entretanto, há também migração contínua de neutrófilos. O reparo do tecido resulta em formação de novos vasos sanguíneos e fibrose (32).

Assim, os macrófagos têm uma função importante tanto para o início quanto para o fim da resposta inflamatória, indicando que sua disfunção pode acarretar em graves complicações no organismo. No momento em que a infecção é estabelecida, os macrófagos residentes do tecido são responsáveis por sinalizar ao organismo e atrair neutrófilos para o foco inflamatório. Ali, ambos os leucócitos conduzem a resposta para a destruição dos micro-organismos invasores através da fagocitose e produção de moléculas microbicidas. Além disso, mais macrófagos são recrutados 
através da diferenciação de monócitos circulantes que são atraídos para o local e são essenciais para a fagocitose de debris celulares. Diferentes dos neutrófilos, macrófagos são células apresentadoras de antígenos e assim também participam na transição entre resposta imune inata e adaptativa. E por fim, os macrófagos passam a secretar fatores anti-inflamatórios, os quais desencadeiam a resolução da inflamação, impedindo danos teciduais e evitando uma inflamação crônica.

\section{2 ÁCIDOS GRAXOS}

Ácidos graxos são compostos formados por cadeias hidrocarbonadas de diversos tamanhos e graus de insaturações que terminam em um grupamento carboxila. Ácidos graxos são sistematicamente nomeados de acordo com o número de átomos de carbono e de insaturações. Tradicionalmente, a posição de uma dupla ligação é indicada contando-se os átomos de carbono a partir do grupo carboxila, sendo que o átomo de carbono deste grupamento é denominado carbono 1.0 átomo de carbono na região distal do grupamento carboxila (metil terminal) é chamado de carbono w1 e a classificação de um ácido graxo insaturado pode também ser feita baseando-se na posição da sua primeira dupla ligação em relação a este átomo. Dessa forma, ácidos graxos ômega-6 (n-6) possuem sua primeira ligação no carbono $\omega 6$, enquanto que ácidos graxos ômega-9 (n-9) possuem sua primeira ligação no carbono $\omega 9$, contados a partir do $\omega 1$. As propriedades dos ácidos graxos dependem do número de carbonos e duplas ligações, sendo que quanto mais insaturada e menor o tamanho da cadeia hidrocarbonada, menor será o ponto de fusão e, portanto, maior será a fluidez do ácido graxo (33).

As células podem obter ácidos graxos a partir da dieta, da mobilização de gordura armazenada no tecido adiposo ou sintetizados a partir de carboidratos no fígado. A maior parte da gordura da dieta está sob a forma de triacilglicerol, o qual é formado por três moléculas de ácidos graxos em ligação éster com uma molécula de glicerol. Antes de serem absorvidos, os triacilgliceróis são emulsificados por ácidos biliares no intestino delgado, formando micelas. Isso faz com que uma maior fração de lipídios entre em contato com as lipases no intestino, sendo então convertidos a 
monoacilgliceróis, diacilgliceróis e ácidos graxos livres. Esses produtos da lipólise difundem então para dentro das células epiteliais do intestino, onde são novamente convertidos a triacilgliceróis e posteriormente associadas a colesteróis da dieta e proteínas específicas (apolipoproteínas), formando agregados de lipoproteínas chamados de quilomícrons. Em seguida, os quilomícrons entram nos vasos do sistema linfático e destes vão para a circulação sanguínea. À medida que os quilomícrons passam pelos capilares do tecido adiposo ou muscular, a LPL presente no endotélio hidrolisa os triacilgliceróis, disponibilizando ácidos graxos para os adipócitos e células musculares. Uma vez dentro dos adipócitos, eles são novamente armazenados na forma de triaciglicerol até serem hidrolisados em situações como jejum e exercício físico. Os ácidos graxos provenientes da hidrólise dos triacilgliceróis são então transportados no sangue ligados a albumina. Nas células musculares, os ácidos graxos são oxidados gerando energia (34).

Quase todo o conteúdo de triacilglicerol é depletado dos quilomícrons, mas o colesterol e as proteínas permanecem até que os quilomícrons sejam endocitados pelas células do fígado. $O$ excesso de ácidos graxos ou de carboidratos na dieta pode ser convertido a triacilgliceróis no fígado, os quais são posteriormente transportados na circulação em moléculas de VLDL para os tecidos adiposo e muscular, onde sofrem novamente a ação da LPL. A retirada de triacilgliceróis das partículas de VLDL faz com que essas sejam convertidas a IDL e em seguida a LDL, que são ricas em colesterol e ésteres de colesteril e assim transportam esses compostos para tecidos extra-hepáticos. As partículas de HDL são sintetizadas no fígado e intestino e contém a enzima lecitina-colesterol aciltransferase, que converte o colesterol e a fosfatidilcolina dos quilomícrons e VLDL remanescentes em ésteres de colesteril. Além disso, ela retira moléculas de colesterol de tecidos extrahepáticos e as transporta para o fígado. A densidade das lipoproteínas reflete a proporção entre lipídios e proteínas, sendo que um conteúdo maior de lipídios acarreta em uma menor densidade (35).

Os ácidos graxos possuem três funções principais: são elementos de construção de fosfolipídios e glicosídeos, que são componentes das membranas biológicas; podem ser armazenados na forma de triacilgliceróis, sendo importantes moléculas fornecedoras de energia; e apresentam-se como mensageiros intracelulares, modulando várias respostas celulares, incluindo a resposta imune. 
Dessa forma, podem estimular e/ou inibir a produção de citocinas, quimiocinas, fatores de crescimento, ROS, RNS e mediadores lipídicos (36, 37). Mudanças na composição dos ácidos graxos nos fosfolipídios da membrana plasmática influenciam a função da célula de várias formas. Primeiramente, a fluidez da membrana é alterada, o que afeta a atividade de proteínas da membrana. Os fosfolipídios são também fontes de segundos mensageiros como diacilglicerol, ácido fosfatídico, inositol 1,4,5-trisfosfato, ceramida e ácido araquidônico, envolvidos na ativação de diversas vias de sinalização (38). Além disso, os ácidos graxos também modulam respostas diretamente ligando-se a TLRs, PPARs e enzimas como lipo e ciclo-oxigenases, alterando assim a síntese de mediadores inflamatórios (36).

O primeiro estudo demonstrando efeitos de ácidos graxos no sistema imune foi feito em 1970, quando Pipette e Saugier realizaram uma infusão lipídica em coelhos e verificaram alterações nas funções de leucócitos (39). Desde então, muitos estudos foram feitos para avaliar os efeitos da ingestão de ácidos graxos na resposta imunológica. De forma geral, grande parte destes estudos demonstra um efeito anti-inflamatório dos ácidos graxos n-3 e pró-inflamatório dos n-6, enquanto que há poucos estudos sobre ácidos graxos n-9 e seus efeitos ainda são controversos. Os ácidos graxos n-3 e n-6 são as principais famílias de PUFAs, ou seja, que possuem mais de uma dupla-ligação. Já o ácido oleico, o ácido graxo n-9 mais conhecido, é um MUFA (40).

O primeiro ácido graxo da família dos n-6 é o ácido linoleico, encontrado em óleos vegetais de soja, girassol e milho, enquanto que o dos $n-3$ é o ácido $\alpha$ linolênico que, por sua vez, é encontrado em óleo de soja, linhaça e alguns tipos de castanhas. Ambos são ácidos graxos essenciais e juntos constituem mais de 95\% dos PUFAs ingeridos diariamente nas dietas ocidentais (41). Como já citado acima, os PUFAs podem alterar a resposta inflamatória por serem precursores de substratos da síntese de eicosanoides. O ácido linoleico pode sofrer diversas alterações e por fim gerar ácido araquidônico, o qual é substrato das lipo e ciclooxigenases, e assim é convertido principalmente em mediadores lipídicos com atividades pró-inflamatórias, embora também possa gerar as lipoxinas. Já o ácido $\alpha$ linolênico pode gerar EPA e DHA, apesar desta reação ser um tanto ineficiente, que por fim são convertidos a resolvinas e protectinas, mediadores lipídicos com atividades anti-inflamatórias e de pró-resolução da inflamação (40). O ácido oleico 
não é essencial e, portanto, pode ser sintetizado de novo. Ainda assim, ele é um dos ácidos graxos mais consumidos no mundo, podendo corresponder a um terço da ingestão diária total de ácidos graxos. Embora seus efeitos no sistema imune ainda sejam controversos, há evidências de um efeito anti-inflamatório deste ácido graxo (42) (Figura 1).

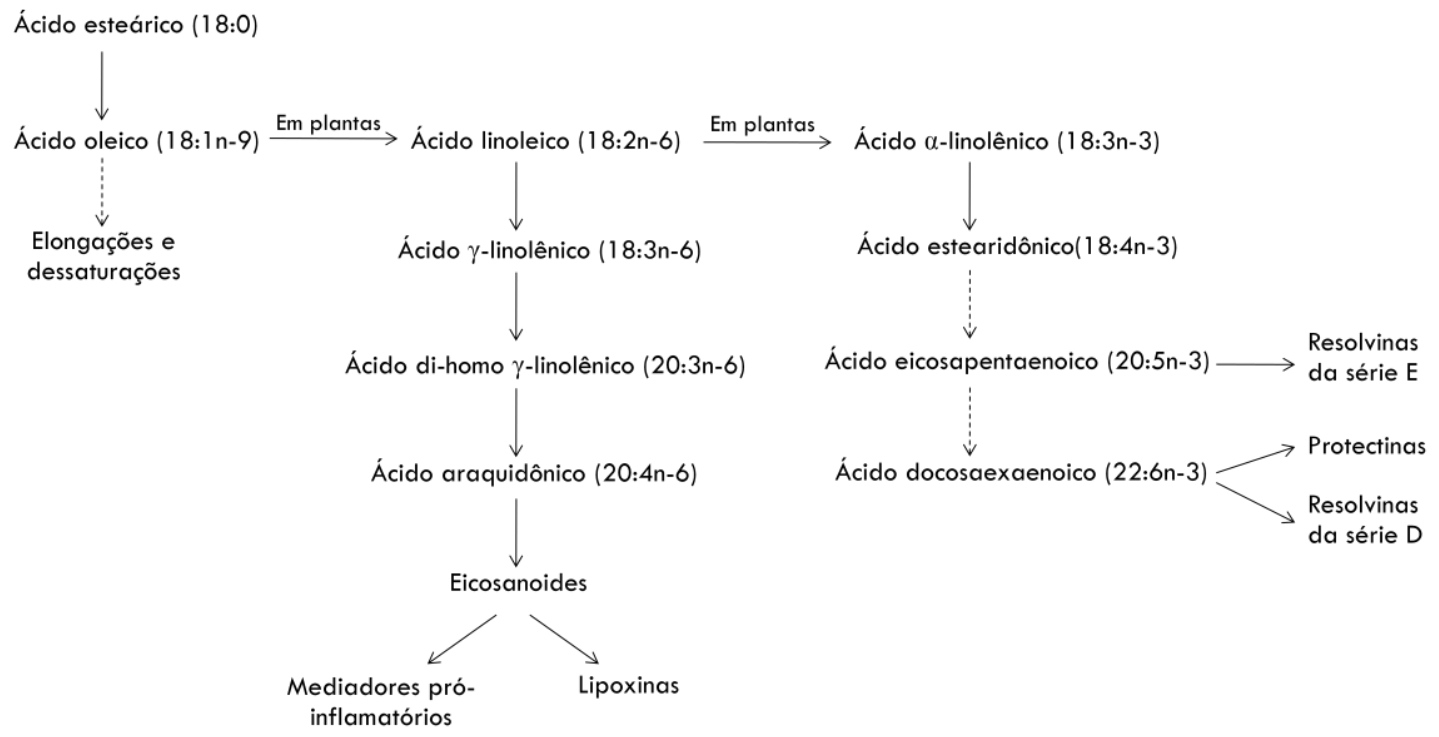

Figura 1. Metabolismo de ácidos graxos. Eles estão indicados pelos nomes e em parênteses encontram-se o número de átomos de carbono e duplas ligações e sua classificação como n-3, n-6 ou n-9. As linhas pontilhadas indicam mais de uma reação. 


\subsection{JUSTIFICATIVA DO TRABALHO}

Macrófagos são fagócitos mononucleares responsáveis não apenas pelo reconhecimento e eliminação de patógenos, mas também por promover a resolução da inflamação, dando início à fase de reparo. Para que esses processos ocorram de forma ordenada e mínimo prejuízo aos tecidos, a síntese de determinados fatores por essas células como ROS, RNS, citocinas, eicosanoides e fatores de crescimento é estritamente regulada (31). Os ácidos graxos podem alterar a função de macrófagos de diversas formas: modulando vias de sinalização intracelulares, ativando fatores de transcrição, ligando-se a TLRs e alterando a produção de mediadores lipídicos (36). De acordo com o Departamento de Agricultura dos Estados Unidos (2007-2008), os ácidos graxos mais consumidos na dieta são os ácidos oleico e linoleico (43), sendo o primeiro presente em carnes, ovos, leite e azeite de oliva e o segundo encontrado em óleos vegetais de soja, girassol e milho, os quais podem ser utilizados na produção de alimentos e alimentação de animais $(41,44)$. Assim, este estudo teve como objetivo estudar os efeitos da ingestão dos ácidos oleico ou linoleico na produção de mediadores inflamatórios em macrófagos de ratos e comparar com os efeitos exercidos pelos tratamentos in vitro com os mesmos ácidos graxos. É frequente especular sobre implicações fisiológicas a partir de achados in vitro. Contudo, deve-se testar se o efeito in vivo é mesmo equivalente ao in vitro.

\subsection{HIPÓTESES}

Considerando que ácidos graxos alteram a função imune, espera-se que os ácidos oleico ou linoleico alterem a produção de mediadores inflamatórios por macrófagos. Além disso, é esperado que os efeitos desencadeados pelos tratamentos in vitro das células sejam reproduzidos nos tratamentos in vivo dos animais com os mesmos ácidos graxos. 


\section{OBJETIVOS}

\subsection{OBJETIVO GERAL}

Investigar os efeitos dos tratamentos com os ácidos oleico ou linoleico in vitro e in vivo na produção de mediadores inflamatórios por macrófagos.

\subsection{OBJETIVOS ESPECÍFICOS}

Após tratamento in vitro ou suplementação de ratos por 10 dias com os ácidos oleico ou linoleico, a produção dos seguintes mediadores inflamatórios foi investigada: ROS; nitrito; TNF- $\alpha$, IL-1 $1 \beta$, IL-6, CINC-2 $\alpha \beta$ e VEGF. Em seguida, os efeitos induzidos pelos tratamentos in vitro foram comparados àqueles desencadeados pelos tratamentos in vivo. 


\section{MATERIAL E MÉTODOS}

\subsection{MATERIAL}

Os ácidos graxos (oleico e linoleico), LPS de E.coli sorotipo 026:B6, PMA, Lglutamina, Hepes, penicilina, SFB, lucigenina, kit para determinação de crescimento celular baseado em MTT, iodeto de propídeo, HRP tipo II foram obtidos da SigmaAldrich (Sigma-Aldrich Co, St. Louis, MO, EUA). O meio de cultura RPMI 1640 e o Amplex ${ }^{\circledR}$ Ultrared foram obtidos da Invitrogen (Invitrogen, Carlsbad, CA, EUA). Os kits DuoSet para determinação das citocinas foram adquiridos da R\&D Systems (R\&D Systems, Minneapolis, MN, EUA).

\subsection{MÉTODOS}

\subsubsection{Animais}

Foram utilizados ratos Wistar $(300 \pm 20 \mathrm{~g})$ obtidos do Departamento de Fisiologia e Biofísica, Instituto de Ciências Biomédicas, Universidade de São Paulo. Os ratos foram mantidos em ambiente controlado à temperatura de $23^{\circ} \mathrm{C}$, sob ciclo claro:escuro de 12 horas e tiveram livre acesso à agua e à ração (Nuvital, Curitiba, PR, Brasil - contendo 22\% proteína, 4,5\% gordura, 40,8\% carboidrato e $8 \%$ fibra, atingindo $3 \mathrm{kcal} / \mathrm{g}$ de energia total metabolizada). A composição dos ácidos graxos da ração pode ser visualizada em outro estudo do grupo (45). Os animais foram sacrificados após aproximadamente $4 \mathrm{~h}$ do início do seu ciclo claro.

Todos os procedimentos realizados neste estudo foram aprovados pela Comissão de Ética em Experimentação Animal (CEEA) do Instituto de Ciências Biomédicas da Universidade de São Paulo (Protocolo número 86). 


\subsubsection{Suplementação dos animais}

Os ratos foram tratados por via oral com $50 \mu \mathrm{L}$ de água (controle), ácido oleico ou ácido linoleico diariamente durante 10 dias, o que equivale a $0,15 \mathrm{~g} / \mathrm{kg}$ de peso corporal/dia. No décimo dia, o sacrifício dos animais foi realizado $1 \mathrm{~h}$ após a suplementação. Esta dose não é tóxica aos animais, como verificado em estudo prévio do grupo pela atividade de enzimas no soro (alanina transaminase, aspartato transaminase, lactato desidrogenase) e pela análise morfológica do intestino, e não altera os parâmetros nutricionais (consumo alimentar e calórico e ingestão de água) (45).

\subsubsection{Separação e cultura de células peritoneais de ratos}

As células peritoneais foram obtidas por lavagem intraperitoneal. Após a morte por decapitação, foram injetados $50 \mathrm{~mL}$ de PBS (cloreto de sódio 136,8 mM, cloreto de potássio $2,7 \mathrm{mM}$, fosfato de potássio $0,9 \mathrm{mM}$, fosfato de sódio dibásico 6,4 mM; pH: 7,4) no peritônio do rato. Após massagear a região abdominal, o PBS contendo as células foi retirado. A solução foi centrifugada $\left(500 \mathrm{~g}, 4^{\circ} \mathrm{C}, 10 \mathrm{~min}\right)$ e o sobrenadante foi descartado, ficando apenas o precipitado celular. Para lisar hemácias, adicionou-se $5 \mathrm{~mL}$ de solução hiposmótica de cloreto de amônia (cloreto de amônia $150 \mathrm{mM}$, bicarbonato de sódio $10 \mathrm{mM}$, EDTA 0,1 mM; pH: 7,4) com posterior centrifugação, nas mesmas condições. As células foram mantidas em $1 \mathrm{~mL}$ de PBS e contadas em câmera de Neubauer. Em seguida, foram centrifugadas nas mesmas condições acima descritas e o sobrenadante foi descartado. As células foram então ressuspendidas em meio de cultura RPMI contendo $10 \%$ de SFB, plaqueadas (concentração dependente do experimento) e depois incubadas a $37^{\circ} \mathrm{C}$ em atmosfera de $5 \%$ de $\mathrm{CO}_{2}$. Uma hora após o início da incubação, as células não aderentes foram retiradas dos poços por lavagem com meio de cultura. Esse procedimento foi utilizado com o intuito de enriquecer a cultura em macrófagos (células aderentes). 


\subsubsection{Tratamento in vitro das células}

Após adesão celular, adicionou-se os ácidos graxos nas concentrações de 25 $\mu \mathrm{M}, 50 \mu \mathrm{M}$ ou $100 \mu \mathrm{M}$ (exceto nas células isoladas dos animais suplementados) e/ou outros tratamentos (PMA ou LPS), quando pertinentes (o tempo de tratamento foi considerado a partir deste momento). Foi utilizado etanol (diluente) como tratamento controle in vitro, sendo que sua concentração não ultrapassou $0,16 \%$.

\subsubsection{Análise de citotoxicidade por citometria de fluxo}

Para avaliar a toxicidade dos ácidos graxos foi feito o ensaio de fragmentação de DNA por citometria de fluxo. Para os ensaios de tratamento in vitro, macrófagos ( $10^{6}$ células) foram incubados em placas de 24 poços e tratados com $100 \mu \mathrm{M}$ (maior concentração utilizada nos outros experimentos) dos ácidos oleico ou linoleico em RPMI ( $10 \%$ SFB) no volume final de $1 \mathrm{~mL}$. Após $24 \mathrm{~h}$ de tratamento (tempo máximo utilizado nos experimentos), as células foram retiradas da placa com o uso de tripsina. Já para os macrófagos dos ratos suplementados ( $10^{6}$ células), a análise da fragmentação de DNA foi feita logo em seguida à separação das células (sem incubação em placa). Resumidamente, as células foram ressuspendidas em $300 \mu \mathrm{L}$ de tampão de lise $(0,1 \%$ citrato de sódio e $0,1 \%$ Triton X-100) contendo $20 \mu \mathrm{g} / \mathrm{mL}$ de iodeto de propídeo e incubadas no escuro por 30 minutos. As amostras foram então analisadas (10.000 eventos por amostra) por citometria de fluxo (FACSCalibur, Becton Dickinson, San Juan, CA, EUA) usando o programa Cell Quest. O iodeto de propídeo é um composto solúvel em água que não atravessa a membrana plasmática intacta. $\mathrm{Na}$ análise do DNA fragmentado, o iodeto de propídeo se intercala no DNA exposto (após a lise das células) e foi identificado por fluorescência laranja/vermelha $(585 / 42 \mathrm{~nm})$. A presença de fragmentos com baixa fluorescência é indicativa de clivagem do DNA. 


\subsubsection{Análise de citotoxicidade por ensaio de MTT}

O ensaio de MTT é colorimétrico e permite avaliar a viabilidade celular. Para os ensaios de tratamento in vitro, macrófagos $\left(4 \times 10^{5}\right.$ células) foram incubados em placas de 96 poços e tratados com $100 \mu \mathrm{M}$ (maior concentração utilizada nos outros experimentos) dos ácidos oleico ou linoleico em RPMI (10\% SFB) no volume final de $90 \mu \mathrm{L}$ por $21 \mathrm{~h}$. Após este período de tratamento ou a adesão dos macrófagos isolados dos ratos suplementados (com troca de meio de cultura para volume final de $90 \mu \mathrm{L}$ ), foram adicionados $10 \mu \mathrm{L}$ de MTT (Sigma-Aldrich) em cada amostra. Após 3 horas de incubação a $37^{\circ} \mathrm{C}$, os sobrenadantes das amostras foram descartados e foram adicionados $100 \mu \mathrm{L}$ de solução de $\mathrm{HCl}$ em isopropanol anidro a 0,1 N. Após a dissolução, as amostras foram lidas em espectrofotômetro (Synergy HT Multi-Mode Microplate Reader, Bio-Tek Instruments, Inc., Winooski, VT, EUA) e o resultado foi expresso como a diferença encontrada nos comprimentos de onda $570 \mathrm{~nm}$ e 690 nm, como especificado pelo fornecedor. O sal de MTT, amarelo e solúvel em água, é reduzido pela enzima mitocondrial succinato desidrogenase a cristais de formazan, os quais são dissolvidos pela solução de $\mathrm{HCl}$ em isopropanol, sendo posteriormente mensurados em espectrofotômetro. Dessa forma, a concentração de cristais de formazan está diretamente relacionada com o número de células viáveis presentes na amostra.

\subsubsection{Ensaio de quimiluminescência amplificada por lucigenina}

O ensaio de quimiluminescência na presença de lucigenina (Sigma-Aldrich) é uma forma de quantificar ROS, principalmente o ânion superóxido. Após incubação por $1 \mathrm{~h}$ para isolamento dos macrófagos ( $4 \times 10^{5}$ células em volume final de $200 \mu \mathrm{L}$ ), o sobrenadante da cultura foi descartado e adicionou-se às células PBS suplementado (10\% SFB, $10 \mathrm{mM}$ glicose, 1,5 mM cloreto de magnésio, $1 \mathrm{mM}$ cloreto de cálcio) com lucigenina (1 $\mathrm{mM})$, na ausência ou presença dos ácidos oleico ou linoleico $(25 \mu \mathrm{M}, 50 \mu \mathrm{M}, 100 \mu \mathrm{M})$ e PMA (10 nM), totalizando $250 \mu \mathrm{L}$ de volume final. 
O ensaio foi avaliado em luminômetro (Synergy HT Multi-Mode Microplate Reader) durante $1 \mathrm{~h}$ a $37^{\circ} \mathrm{C}(46)$. A lucigenina, ao ser excitada pelo ânion superóxido, libera energia na forma de luz. Os resultados foram expressos como quimiluminescência ao longo de $1 \mathrm{~h}$, subtraindo-se a leitura do branco (mesmos reagentes, porém sem células) de todos os valores.

\subsubsection{Ensaio de fluorescência utilizando Amplex ${ }^{\circledR}$ Ultrared}

O ensaio de fluorescência utilizando o reagente Amplex ${ }^{\circledR}$ Ultrared (Invitrogen) é outra forma de quantificar ROS, porém detecta principalmente peróxido de hidrogênio. Após incubação por $1 \mathrm{~h}$ para isolamento dos macrófagos (4 × $10^{5}$ células em volume final de $200 \mu \mathrm{L}$ ), adicionou-se às células PBS suplementado (10\% SFB, $10 \mathrm{mM}$ glicose, 1,5 mM cloreto de magnésio, $1 \mathrm{mM}$ cloreto de cálcio) com Amplex ${ }^{\circledR}$ Ultrared $(50 \mu \mathrm{M})$ e HRP tipo II $(0,1 \mathrm{U} / \mathrm{mL})$, na ausência ou presença dos ácidos oleico ou linoleico $(25 \mu \mathrm{M}, 50 \mu \mathrm{M}, 100 \mu \mathrm{M})$ e PMA (10 $\mathrm{nM})$, totalizando volume final de $200 \mu \mathrm{L}$. A placa foi incubada no escuro a 37으 por $1 \mathrm{~h}$, seguido da leitura em fluorímetro (Synergy HT Multi-Mode Microplate Reader) (excitação 530nM/ emissão 590nM). Os resultados foram expressos como fluorescência ao longo de $1 \mathrm{~h}$, subtraindo-se a leitura do branco (mesmos reagentes, porém sem células) de todas as outras leituras. O Amplex ${ }^{\circledR}(\mathrm{N}$-acetil-3,7-diidroxifenoxazina) atua como doador de elétrons para a reação de redução do $\mathrm{H}_{2} \mathrm{O}_{2}$ catalisada pela $\mathrm{HRP}$, na proporção de 1:1. O produto da oxidação do Amplex ${ }^{\circledR}$ pela HRP é denominado resorufina, um composto vermelho, estável e fluorescente, que pode ser quantificado por fluorimetria, sendo uma evidência indireta da quantidade de peróxido de hidrogênio na amostra (47). 
3.2.9 Quantificação de citocinas e VEGF no sobrenadante da cultura de macrófagos

Macrófagos ( $10^{6}$ células) foram incubados em meio RPMI ( $10 \%$ SFB) e volume final de $250 \mu \mathrm{L}$ por $5 \mathrm{~h}$ (para tratamento in vivo) ou $1 \mathrm{~mL}$ por $24 \mathrm{~h}$ (para tratamento in vivo e in vitro), na presença ou ausência dos ácidos oleico ou linoleico $(25 \mu \mathrm{M}, 50 \mu \mathrm{M}, 100 \mu \mathrm{M})$ e LPS $(5 \mu \mathrm{g} / \mathrm{mL})$. A quantificação de TNF- $\alpha, \mathrm{IL}-1 \beta$, CINC$2 \alpha \beta / C X C L 3, I L-6$ e VEGF foi efetuada no sobrenadante das culturas por ensaio imunoenzimático (ELISA) através de kits DuoSet (R\&D Systems). As seguintes etapas foram realizadas: aplicação de $50 \mu \mathrm{L} /$ poço do anticorpo de captura diluído em PBS (1 $\mu \mathrm{g} / \mathrm{mL})$ e incubação durante uma noite; lavagem das placas com tampão de lavagem ( $0,05 \%$ Tween 20 em PBS); aplicação de $150 \mu \mathrm{L} /$ poço de reagente diluente (1\% SFB em PBS) por $1 \mathrm{~h}$ para o bloqueio das ligações inespecíficas; lavagem das placas; aplicação de $50 \mu \mathrm{L} /$ poço das amostras (diluídas em reagente diluente, dependendo da citocina) e dos padrões diluídos em reagente diluente; incubação por $2 \mathrm{~h}$; lavagem das placas; aplicação de $50 \mu \mathrm{L} /$ poço do anticorpo de detecção diluído em reagente diluente ( $100 \mathrm{ng} / \mathrm{mL})$; incubação por $2 \mathrm{~h}$; lavagem das placas; aplicação de $50 \mu \mathrm{L} /$ poço de Streptavidin-HRP; incubação por $20 \mathrm{~min}$; lavagem das placas; aplicação de $50 \mu \mathrm{L} /$ poço de solução substrato fornecida pelo fabricante; incubação por $20 \mathrm{~min}$; aplicação de $25 \mu \mathrm{L}$ /poço de solução stop $\left(2 \mathrm{~N} \mathrm{H}_{2} \mathrm{SO}_{4}\right.$ ); leitura das placas em espectrofotômetro (Synergy HT Multi-Mode Microplate Reader) a 450 nm. Para a quantificação das amostras, uma curva padrão com diferentes concentrações da citocina foi utilizada e, após a leitura em espectrofotômetro, a equação da curva padrão (curva do tipo quatro parâmetros) foi obtida de acordo com o procedimento descrito pelo fabricante.

\subsubsection{Quantificação de nitrito}

Macrófagos ( $10^{6}$ células) foram incubados em meio RPMI (10\% SFB) e volume final de $1 \mathrm{~mL}$, por $24 \mathrm{~h}$, na presença ou ausência dos ácidos oleico ou linoleico $(25 \mu \mathrm{M}, 50 \mu \mathrm{M}, 100 \mu \mathrm{M})$ e LPS $(5 \mu \mathrm{g} / \mathrm{mL})$. A quantificação de nitrito, um 
derivado do óxido nítrico, foi realizada a partir do sobrenadante das amostras. Foram utilizados $100 \mu \mathrm{L}$ de cada amostra em uma placa de 96 poços. Às amostras, foram adicionados $100 \mu \mathrm{L}$ do reagente de Griess (1\% sulfanilamida em $5 \% \mathrm{H}_{3} \mathrm{PO}_{4}$ e 0,1\% a-naftil etilenodiamina em água destilada, na proporção 1:1). A curva padrão foi feita com nitrito de sódio $(0-80 \mu \mathrm{M})$ e a leitura da placa foi realizada em espectrofotômetro (Synergy HT Multi-Mode Microplate Reader) a $550 \mathrm{~nm}$ (48). Os resultados foram expressos como produção de nitrito, subtraindo da leitura do branco (somente meio de cultura RPMI). O nitrito presente nas amostras reage com a sulfanilamida formando sal de diazônio, que é convertido em um composto de coloração rosada após a adição do $\alpha$-naftil etilenodiamina.

\subsubsection{Análise estatística}

Os resultados estão apresentados como média \pm EPM. Comparações entre as diferentes concentrações dos tratamentos in vitro foram realizadas por ANOVA uma via, pareada e com pós-teste de Dunnett. Comparações entre os grupos suplementados foram realizadas por ANOVA uma via com pós-teste de Dunnett. As análises estatísticas foram feitas utilizando o programa Prisma 5 (Graph Pad Software, Inc., San Diego, CA, EUA). As diferenças foram consideradas significantes para $\mathrm{p}<0,05$. 


\section{RESULTADOS}

\subsection{TOXICIDADE DOS ÁCIDOS GRAXOS EM MACRÓFAGOS}

Para testar a toxicidade dos ácidos oleico e linoleico em macrófagos, foram realizados ensaios de MTT e fragmentação do DNA através de citometria de fluxo após $24 \mathrm{~h}$ de tratamento in vitro com os ácidos graxos ou logo em seguida à adesão (para o ensaio de MTT) ou separação das células (para a análise de fragmentação do DNA) dos ratos suplementados. O tratamento in vitro com $100 \mu \mathrm{M}$ dos ácidos oleico ou linoleico aumentou a absorbância das amostras em 10\%, porém não houve diferença entre os grupos controle e suplementados (Figura 2). Também não houve diferença significativa entre os grupos controle e tratados in vitro ou in vivo quanto à fragmentação de DNA (Figuras 3).

In vitro

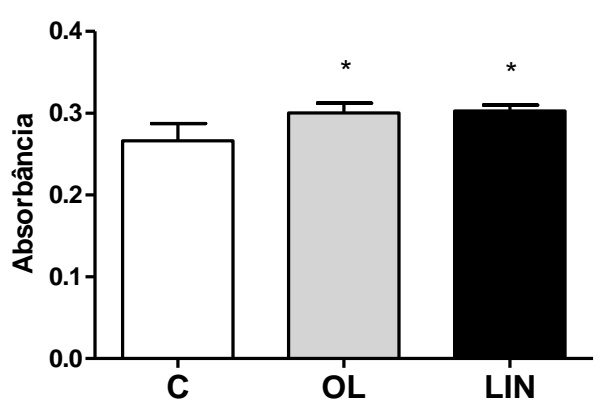

In vivo

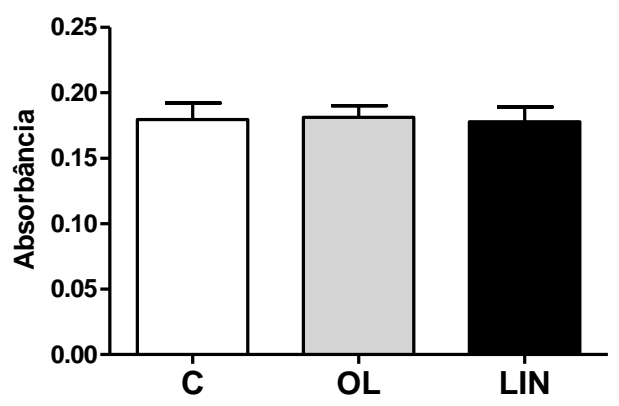

Figura 2. Ensaio de MTT em macrófagos ( $4 \times 10^{5}$ células) isolados do peritônio de ratos, tratados in vitro ou in vivo com etanol (tratamento in vitro) ou água (tratamento in vivo) (C), ácidos oleico (OL) ou linoleico (LIN) por $24 \mathrm{~h}$ (tratamento in vitro) ou 10 dias (tratamento in vivo). Os resultados estão apresentados como média \pm EPM de no mínimo 4 amostras independentes. ${ }^{*} p<0,05$, comparado ao controle (ANOVA pareada com pós-teste Dunnett para tratamento in vitro). 

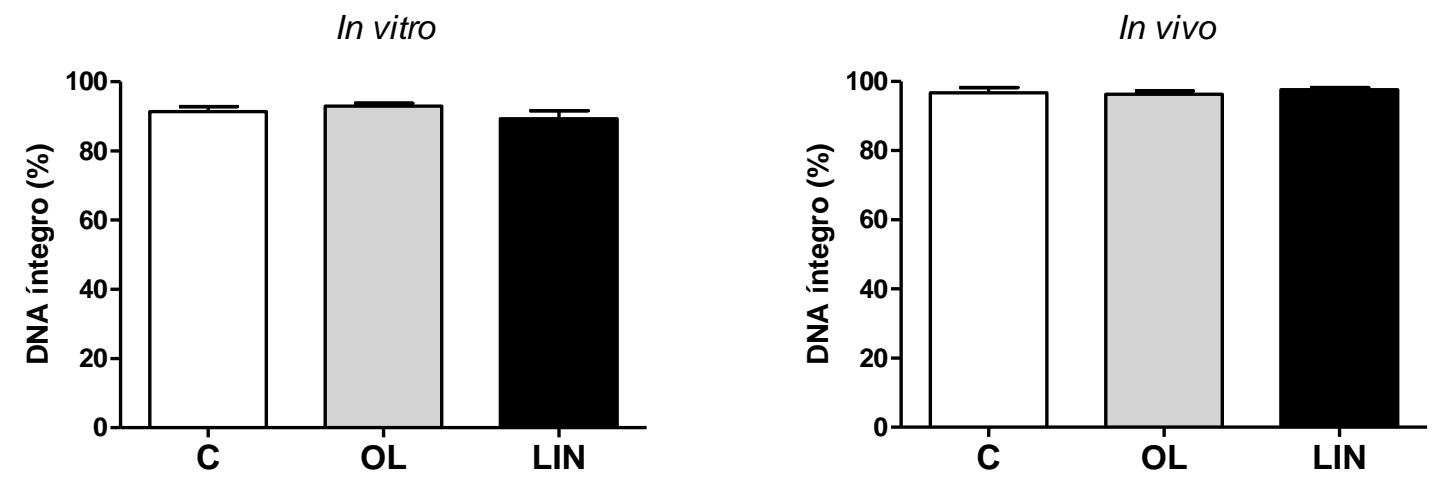

Figura 3. Fragmentação de DNA de macrófagos $\left(10^{6}\right.$ células) isolados do peritônio de ratos, tratados in vitro ou in vivo com etanol (tratamento in vitro) ou água (tratamento in vivo) (C), ácidos oleico (OL) ou linoleico (LIN) por $24 \mathrm{~h}$ (tratamento in vitro) ou 10 dias (tratamento in vivo). Os resultados estão apresentados como média \pm EPM de no mínimo 5 amostras independentes.

\subsection{EFEITO DOS ÁCIDOS OLEICO E LINOLEICO NA PRODUÇÃO DE ROS}

A produção de ânion superóxido durante $1 \mathrm{~h}$ foi analisada através do ensaio de quimiluminescência amplificada por lucigenina. $O$ tratamento in vitro com os ácidos oleico ou linoleico na ausência ou presença de PMA não alterou a produção de superóxido (Figuras 4). Os macrófagos isolados dos ratos suplementados com os ácidos oleico ou linoleico também não apresentaram diferença significativa em relação ao controle (Figura 5). 
Sem PMA

Com PMA

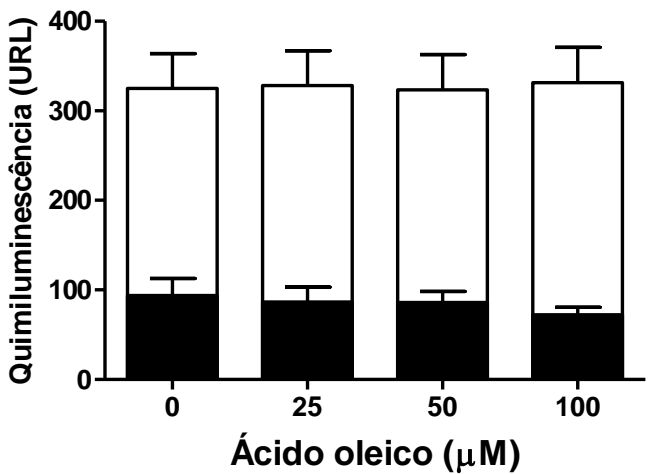

Sem PMA

Com PMA

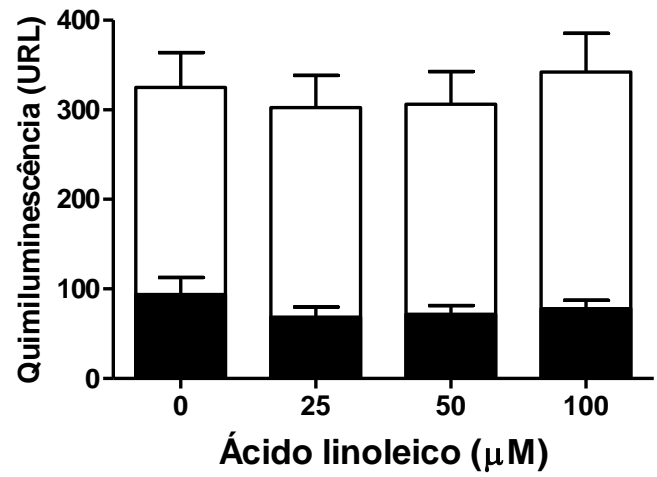

Figura 4. Produção de ânion superóxido durante $1 \mathrm{~h}$ por macrófagos $\left(4 \times 10^{5}\right.$ células), isolados do peritônio de ratos, tratados in vitro com etanol (controle), ácidos oleico ou linoleico $(25 \mu \mathrm{M}$, $50 \mu \mathrm{M}, 100 \mu \mathrm{M})$ na ausência ou presença de PMA (10 nM). Os resultados estão apresentados como média \pm EPM de no mínimo 8 amostras independentes avaliadas em duplicata.

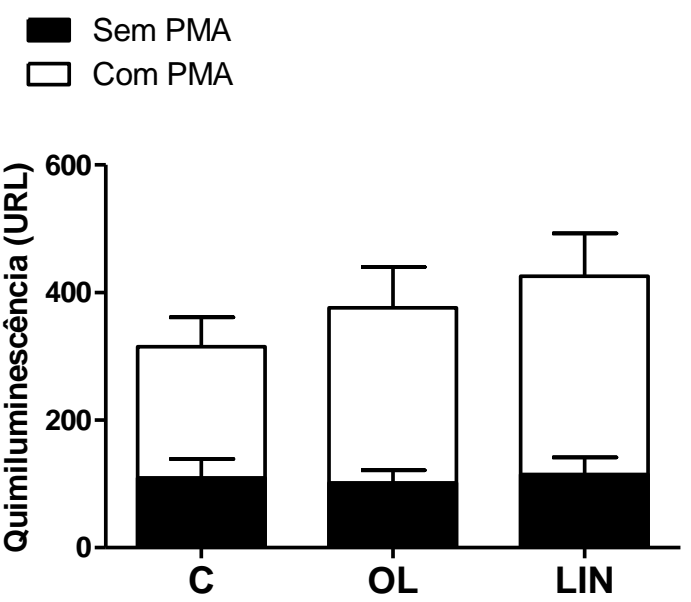

Figura 5. Produção de ânion superóxido durante $1 \mathrm{~h}$ por macrófagos $\left(4 \times 10^{5}\right.$ células $)$ isolados do peritônio de ratos suplementados com água (C), ácidos oleico (OL) ou linoleico (LIN) por 10 dias e incubados na ausência ou presença de PMA (10 nM). Os resultados estão apresentados como média \pm EPM de 10 amostras independentes avaliadas em duplicata.

A produção de peróxido de hidrogênio durante $1 \mathrm{~h}$ foi avaliada por ensaio de fluorescência utilizando Amplex ${ }^{\circledR}$ Ultrared. $O$ tratamento in vitro com $50 \mu \mathrm{M}$ do ácido oleico ou $25 \mu \mathrm{M}$ do ácido linoleico, na ausência de PMA, reduziu significativamente a produção de peróxido de hidrogênio em 15\%. Na presença de PMA, o tratamento in vitro com os ácidos graxos não alterou esta produção (Figuras 6). Os macrófagos isolados dos ratos suplementados com os ácidos oleico ou linoleico não 
apresentaram diferença significativa em relação ao controle na produção de peróxido de hidrogênio, tanto na ausência quanto na presença de PMA (Figura 7).

Sem PMA

Com PMA

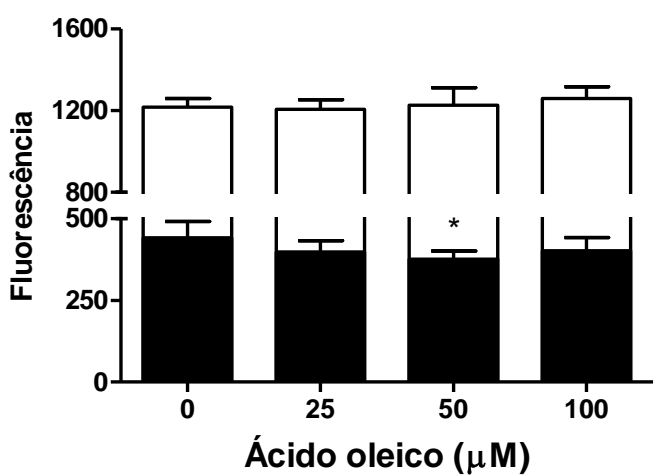

Sem PMA

Com PMA

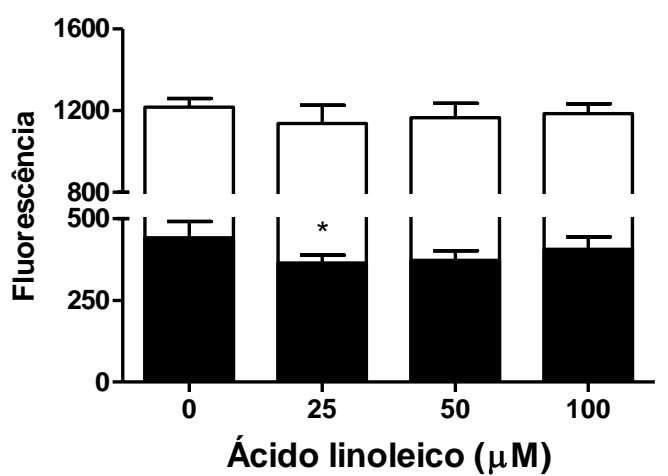

Figura 6. Produção de peróxido de hidrogênio durante $1 \mathrm{~h}$ por macrófagos $\left(4 \times 10^{5}\right.$ células), isolados do peritônio de ratos, tratados in vitro com etanol (controle), ácidos oleico ou linoleico (25 $\mu \mathrm{M}, 50 \mu \mathrm{M}, 100 \mu \mathrm{M})$ na ausência ou presença de PMA (10 nM). Os resultados estão apresentados como média \pm EPM de 9 amostras independentes avaliadas em duplicata. ${ }^{*} \mathrm{p}<0,05$, comparado ao controle sem PMA (ANOVA pareada com pós-teste Dunnett).
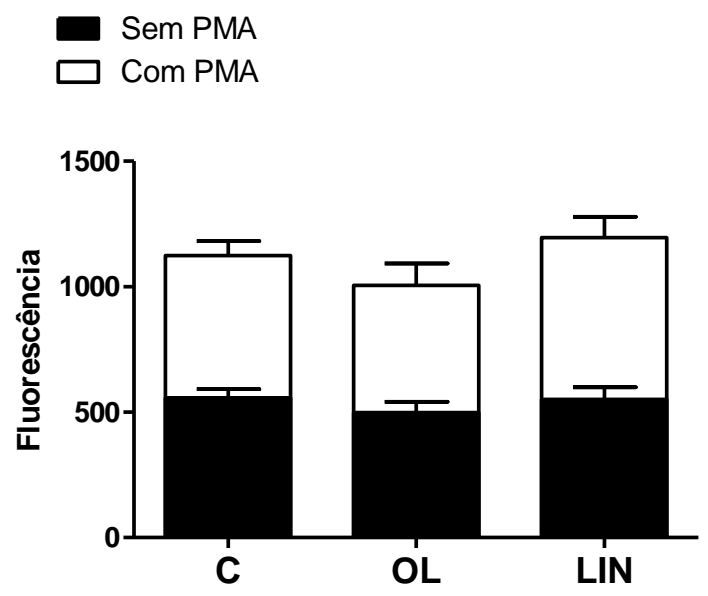

Figura 7. Produção de peróxido de hidrogênio durante $1 \mathrm{~h}$ por macrófagos $\left(4 \times 10^{5}\right.$ células $)$ isolados do peritônio de ratos suplementados com água (C), ácidos oleico (OL) ou linoleico (LIN) por 10 dias e incubados na ausência ou presença de PMA (10 nM). Os resultados estão apresentados como média \pm EPM de no mínimo 9 amostras independentes avaliadas em duplicata. 


\subsection{EFEITO DOS ÁCIDOS OLEICO E LINOLEICO NA PRODUÇÃO DE NITRITO}

Macrófagos tratados in vitro com $100 \mu \mathrm{M}$ do ácido oleico sem LPS produziram $13 \%$ menos nitrito que o controle. Além disso, o tratamento com $25 \mu \mathrm{M}, 50 \mu \mathrm{M}$ e 100 $\mu \mathrm{M}$ de ácido oleico reduziu em $9 \%$ a produção de nitrito por células estimuladas com LPS. O tratamento in vitro com o ácido linoleico sem LPS diminuiu a produção de nitrito em $30 \%$ para a concentração de $100 \mu \mathrm{M}$, e o tratamento com $25 \mu \mathrm{M}, 50 \mu \mathrm{M}$ e $100 \mu \mathrm{M}$ deste ácido graxo levou a uma redução de $8 \%$ nesta produção em células estimuladas com LPS (Figura 8). Já os macrófagos dos ratos suplementados com ácido graxo na ausência ou presença de LPS não tiveram diferença significativa em relação ao controle (Figura 9).

Sem LPS

Com LPS

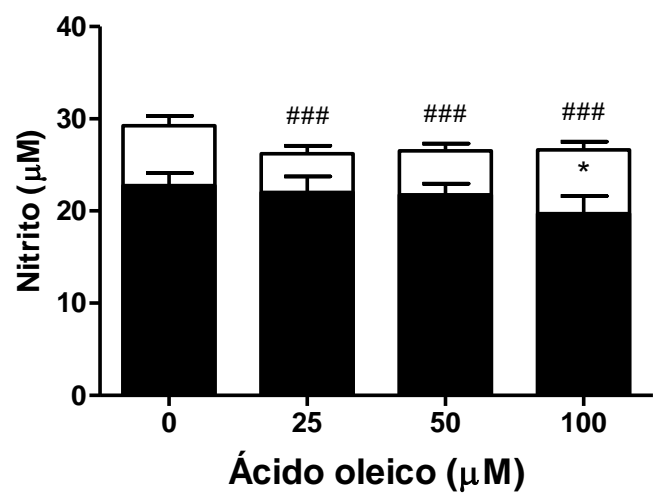

Sem LPS

Com LPS

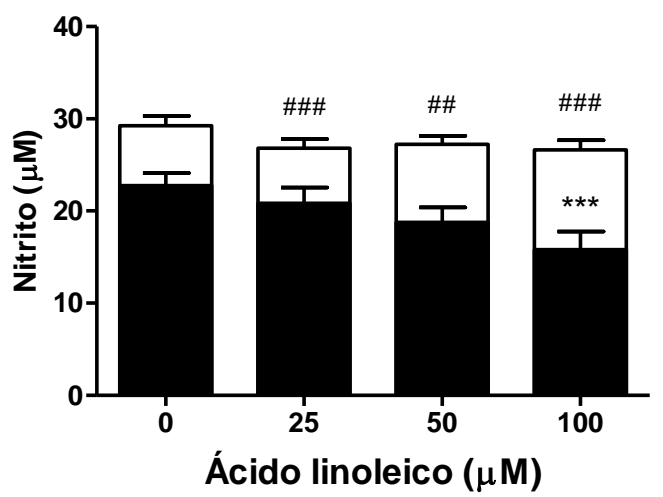

Figura 8. Produção de nitrito por macrófagos $\left(10^{6}\right.$ células), isolados do peritônio de ratos, tratados in vitro com etanol (controle), ácidos oleico ou linoleico $(25 \mu \mathrm{M}, 50 \mu \mathrm{M}, 100 \mu \mathrm{M})$ na ausência ou presença de LPS $(5 \mu \mathrm{g} / \mathrm{mL})$ por $24 \mathrm{~h}$. Os resultados estão apresentados como média \pm EPM de no mínimo 12 amostras independentes. ${ }^{*} \mathrm{p}<0,05$ e ${ }^{* * *} \mathrm{p}<0,001$, comparado ao

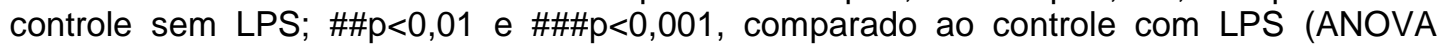
pareada com pós-teste Dunnett). 


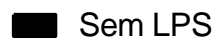

$\square$ Com LPS

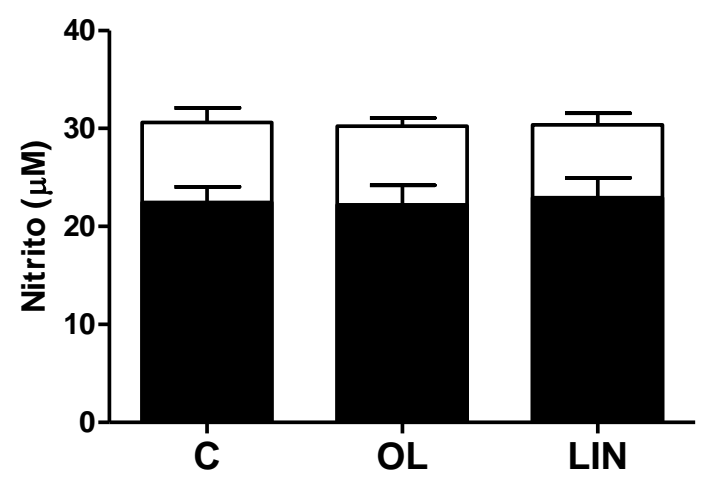

Figura 9. Produção de nitrito durante 5 ou $24 \mathrm{~h}$ por macrófagos $\left(10^{6}\right.$ células) isolados do peritônio de ratos suplementados com água (C), ácidos oleico (OL) ou linoleico (LIN) por 10 dias e incubados na ausência ou presença de LPS $(5 \mu \mathrm{g} / \mathrm{mL})$. Os resultados estão apresentados como média \pm EPM de 9 amostras independentes.

\subsection{EFEITO DOS ÁCIDOS OLEICO E LINOLEICO NA PRODUÇÃO DE CITOCINAS E VEGF}

A produção de TNF- $\alpha$ ao longo de $24 \mathrm{~h}$ não foi alterada quando macrófagos foram tratados in vitro com os ácidos oleico ou linoleico, embora tenha sido reduzida quando as células foram tratadas com estes ácidos graxos e LPS. Assim, nas células tratadas com LPS, a adição de ácido oleico reduziu a produção de TNF- $\alpha$ em $17 \%$ e $23 \%$ para as concentrações de $50 \mu \mathrm{M}$ e $100 \mu \mathrm{M}$, respectivamente, enquanto que o tratamento com ácido linoleico reduziu em 19\%, 19\% e 30\% para as concentrações de $25 \mu \mathrm{M}, 50 \mu \mathrm{M}$ e $100 \mu \mathrm{M}$, respectivamente (Figura 10). Macrófagos isolados de ratos suplementados com os ácidos oleico ou linoleico e incubados por 5 horas na ausência de LPS apresentaram redução de 55\% e 47\%, respectivamente, na produção de TNF- $\alpha$. Entretanto, quando essas células foram incubadas por 5 horas na presença de LPS ou 24 horas na ausência ou presença de LPS, a produção desta citocina não foi alterada (Figura 11). 
Sem LPS

Com LPS

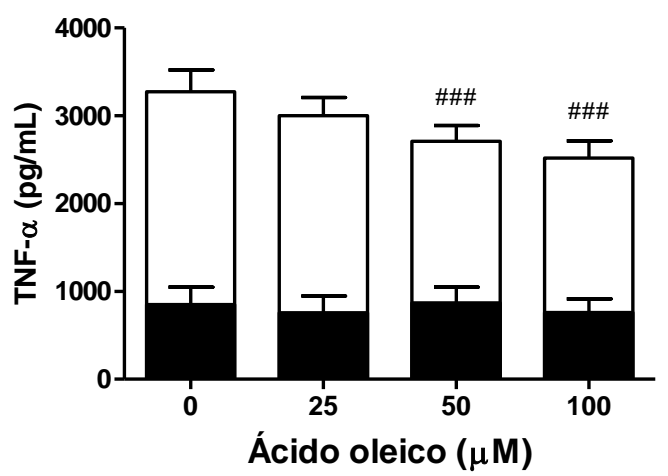

Sem LPS

Com LPS

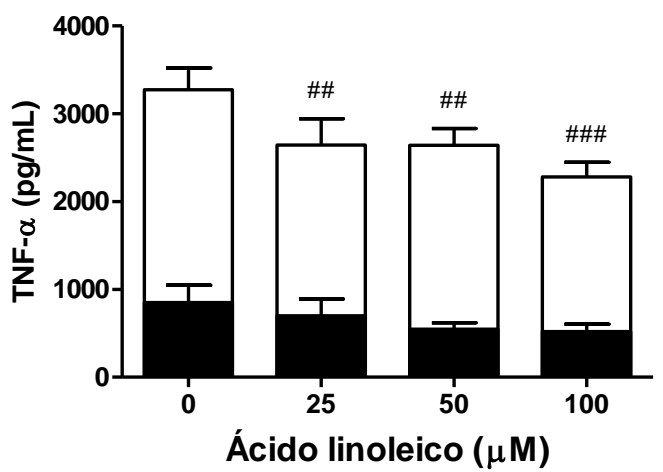

Figura 10. Produção de TNF-a por macrófagos $\left(10^{6}\right.$ células), isolados do peritônio de ratos, tratados in vitro com etanol (controle), ácidos oleico ou linoleico $(25 \mu \mathrm{M}, 50 \mu \mathrm{M}, 100 \mu \mathrm{M})$ na ausência ou presença de LPS $(5 \mu \mathrm{g} / \mathrm{mL})$ por $24 \mathrm{~h}$. Os resultados estão apresentados como média \pm EPM de no mínimo 15 amostras independentes. ${ }^{\#} p<0,01$ e \#\# $p<0,001$, comparado ao controle com LPS (ANOVA pareada com pós-teste Dunnett).

Sem LPS

Com LPS

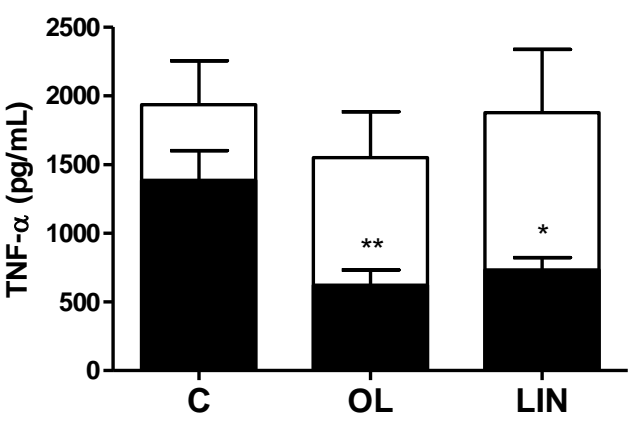

Sem LPS

Com LPS

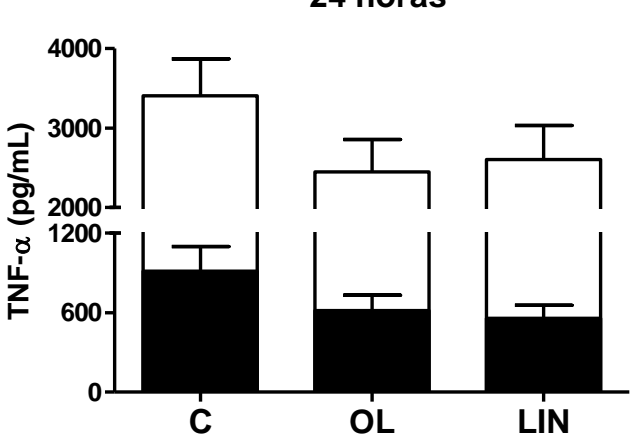

Figura 11. Produção de TNF-a durante 5 ou 24 h por macrófagos ( $10^{6}$ células) isolados do peritônio de ratos suplementados com água (C), ácidos oleico (OL) ou linoleico (LIN) por 10 dias e incubados na ausência ou presença de LPS $(5 \mu \mathrm{g} / \mathrm{mL})$. Os resultados estão apresentados como média \pm EPM de 5 (para incubação de 5 h) e no mínimo 14 (para incubação de 24 h) amostras independentes.

A produção de IL-1 $\beta$ não foi alterada quando macrófagos foram tratados in vitro com os ácidos oleico ou linoleico, na ausência ou presença de LPS (Figura 12). Entretanto, a suplementação com os ácidos oleico ou linoleico reduziu a produção de IL-1 $\beta$ na ausência de LPS em 50\% e $61 \%$, respectivamente, quando as células foram incubadas por 24 horas. $O$ tratamento in vivo com ácido linoleico também 
diminuiu esta produção em $61 \%$ quando os macrófagos foram incubados por 5 horas sem LPS. Na presença de LPS, macrófagos isolados dos animais suplementados com ácidos graxos não alteraram a produção de IL-1ß (Figura 13).

Sem LPS
Com LPS

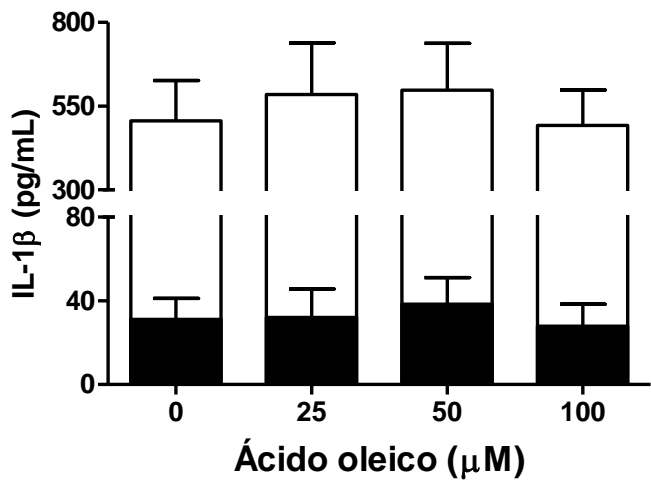

Sem LPS

Com LPS

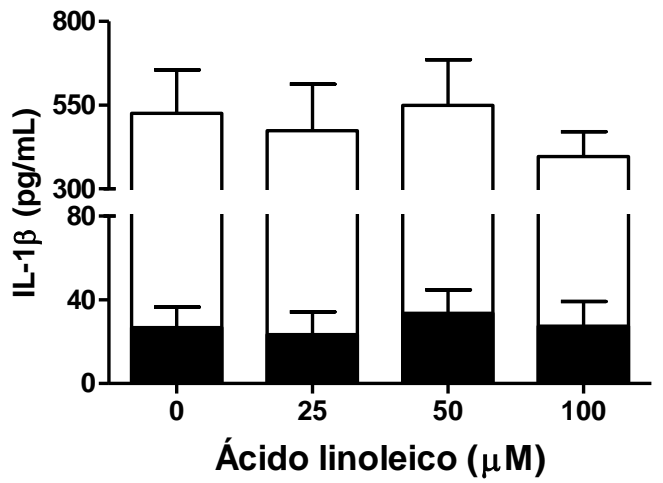

Figura 12. Produção de IL-1 $\beta$ por macrófagos ( $10^{6}$ células), isolados do peritônio de ratos, tratados in vitro com etanol (controle), ácidos oleico ou linoleico $(25 \mu \mathrm{M}, 50 \mu \mathrm{M}, 100 \mu \mathrm{M})$ na ausência ou presença de LPS ( $5 \mu \mathrm{g} / \mathrm{mL}$ ) por $24 \mathrm{~h}$. Os resultados estão apresentados como média \pm EPM de no mínimo 12 amostras independentes.

Sem LPS
Com LPS

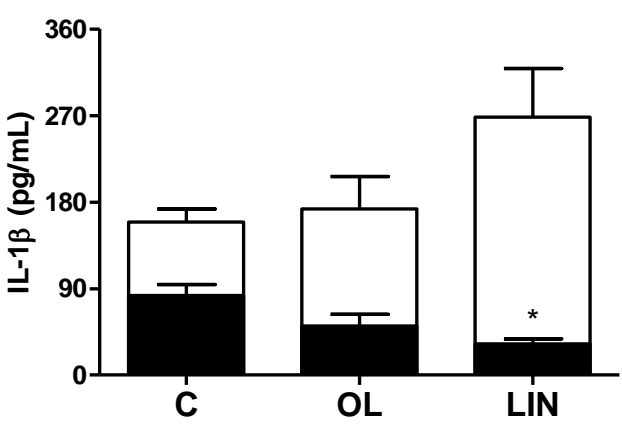

Sem LPS

$\square$ Com LPS

24 horas

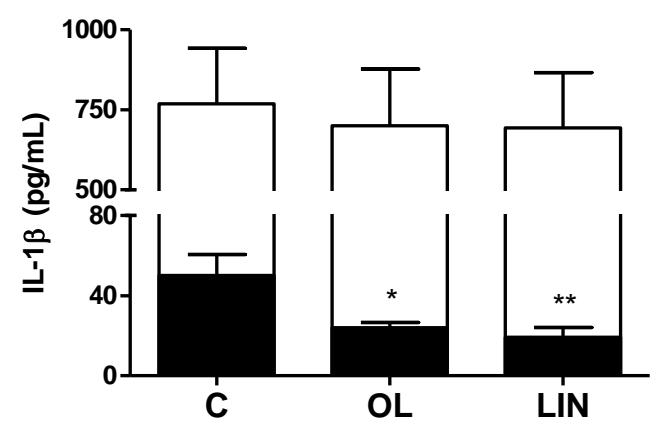

Figura 13. Produção de IL-1 $\beta$ durante 5 ou $24 \mathrm{~h}$ por macrófagos $\left(10^{6}\right.$ células) isolados do peritônio de ratos suplementados com água (C), ácidos oleico (OL) ou linoleico (LIN) por 10 dias e incubados na ausência ou presença de LPS $(5 \mu \mathrm{g} / \mathrm{mL})$. Os resultados estão apresentados como média \pm EPM de no mínimo 3 (para incubação de 5 h) e 10 (para incubação de 24 h) amostras independentes. ${ }^{*} p<0,05 e^{* *} p<0,01$, comparado ao controle sem LPS (ANOVA com pós-teste Dunnett).

Somente o tratamento in vitro com o ácido oleico alterou a produção de IL-6. Na presença de concentrações de $50 \mu \mathrm{M}$ e $100 \mu \mathrm{M}$ desse ácido graxo e ausência de LPS, houve aumento da produção de IL-6 em 1,5 e 1,6 vezes quando comparadas 
ao controle. Na presença de LPS, o tratamento com $25 \mu \mathrm{M}, 50 \mu \mathrm{M}$ e $100 \mu \mathrm{M}$ de ácido oleico elevou a produção em 1,2, quando comparado ao controle com LPS (Figuras 14). Quando incubados por 5 horas, os macrófagos isolados dos ratos tratados com ácidos oleico ou linoleico tiveram redução de $61 \%$ e $57 \%$, respectivamente, na produção de IL-6 na ausência de LPS. Porém, quando incubados por 24 horas, somente o tratamento in vivo com ácido linoleico provocou redução na produção desta citocina em $55 \%$. Não houve diferença na produção de IL-6 quando macrófagos isolados de animais suplementados com os ácidos graxos foram estimulados por LPS (Figura 15).
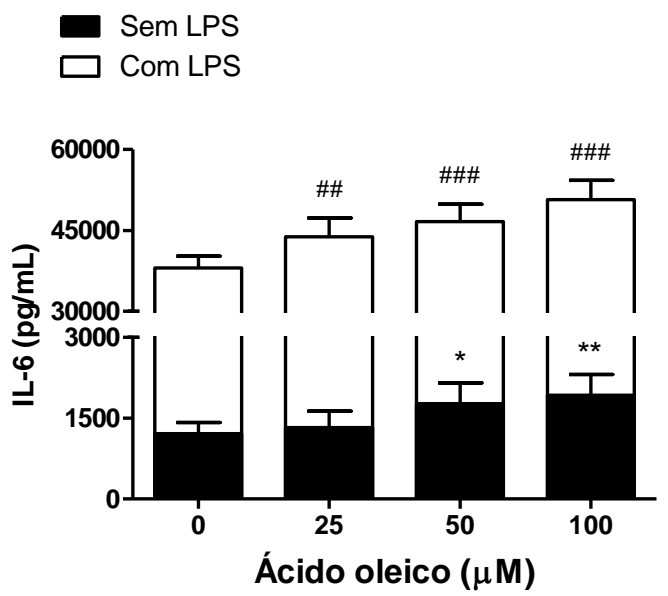

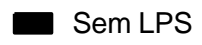

$\square$ Com LPS

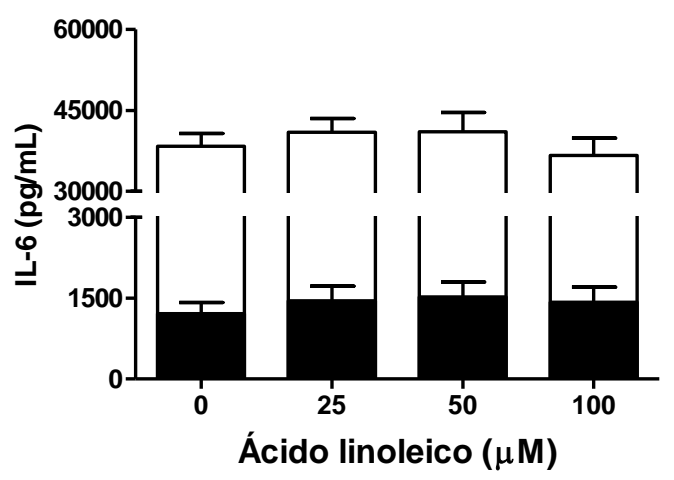

Figura 14. Produção de IL-6 por macrófagos $\left(10^{6}\right.$ células), isolados do peritônio de ratos, tratados in vitro com etanol (controle), ácidos oleico ou linoleico $(25 \mu \mathrm{M}, 50 \mu \mathrm{M}, 100 \mu \mathrm{M})$ na ausência ou presença de LPS ( $5 \mu \mathrm{g} / \mathrm{mL}$ ) por $24 \mathrm{~h}$. Os resultados estão apresentados como média \pm EPM de no mínimo 13 amostras independentes. ${ }^{*} p<0,05$, ${ }^{* *} p<0,01$, comparado ao controle sem LPS; \#\#p<0,01 e \#\#\#p<0,001, comparado ao controle com LPS (ANOVA pareada com pós-teste Dunnett). 

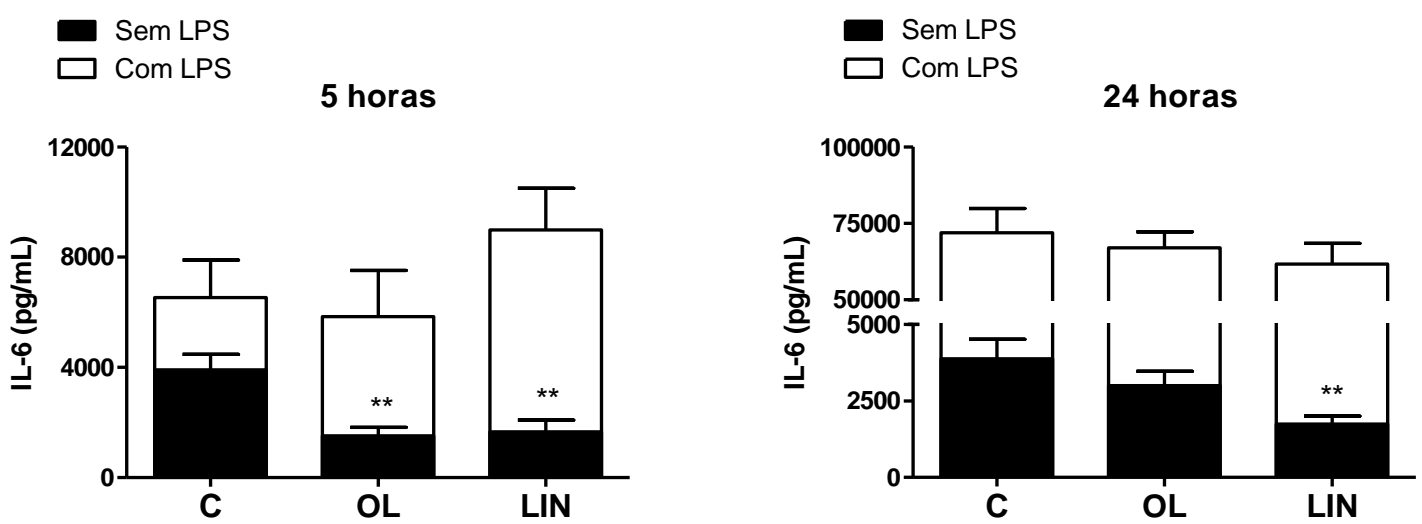

Figura 15. Produção de IL-6 durante 5 ou 24 h por macrófagos $\left(10^{6}\right.$ células) isolados do peritônio de ratos suplementados com água (C), ácidos oleico (OL) ou linoleico (LIN) por 10 dias e incubados na ausência ou presença de LPS $(5 \mu \mathrm{g} / \mathrm{mL})$. Os resultados estão apresentados como média \pm EPM de no mínimo 4 (para incubação de $5 \mathrm{~h}$ ) e no mínimo 13 (para incubação de $24 \mathrm{~h}$ ) amostras independentes. ${ }^{* *} p<0,01$, comparado ao controle sem LPS (ANOVA com pós-teste Dunnett).

A produção de CINC-2 $\alpha \beta$ foi aumentada quando macrófagos foram tratados in vitro com ácidos oleico ou linoleico sem LPS. Com $50 \mu \mathrm{M}$ e $100 \mu \mathrm{M}$ do ácido oleico, a produção dessa citocina foi 1,7 vezes maior que a do controle, enquanto que 50 $\mu \mathrm{M}$ e $100 \mu \mathrm{M}$ do ácido linoleico aumentaram em 1,4 e 1,5 vezes esta produção em comparação ao controle (Figura 16). Já a produção de CINC-2aß pelos macrófagos dos ratos suplementados com os ácidos graxos só foi alterada quando eles foram incubados por 5 horas na ausência de LPS. $O$ tratamento in vivo com ácidos oleico ou linoleico levou à redução de 52\% e 43\% na produção de CINC-2aß (Figura 17). 
Sem LPS

Com LPS

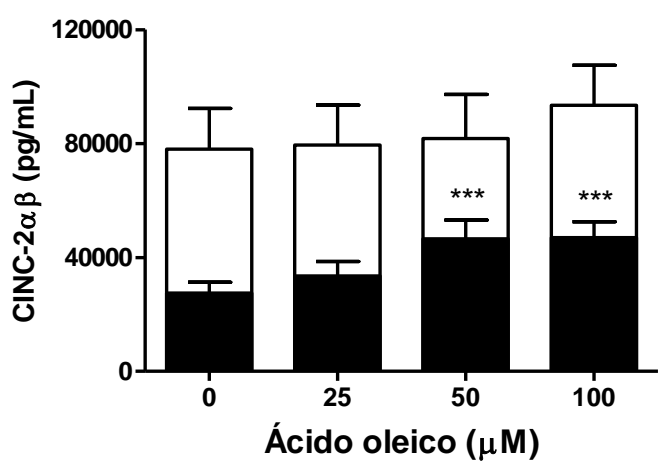

Sem LPS

Com LPS

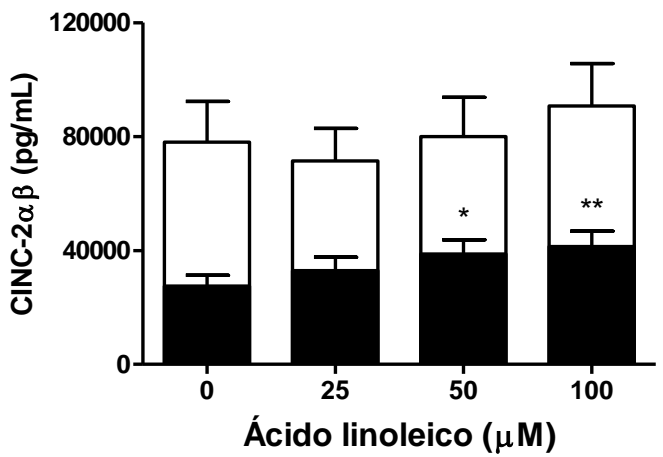

Figura 16. Produção de CINC-2a $\beta$ por macrófagos $\left(10^{6}\right.$ células), isolados do peritônio de ratos, tratados in vitro com etanol (controle), ácidos oleico ou linoleico $(25 \mu \mathrm{M}, 50 \mu \mathrm{M}, 100 \mu \mathrm{M})$ na ausência ou presença de LPS $(5 \mu \mathrm{g} / \mathrm{mL})$ por $24 \mathrm{~h}$. Os resultados estão apresentados como média \pm EPM de no mínimo 15 amostras independentes. $p<0,05,{ }^{* *} p<0,01$ e ${ }^{* * *} p<0,001$, comparado ao controle sem LPS (ANOVA pareada com pós-teste Dunnett).

Sem LPS

Com LPS

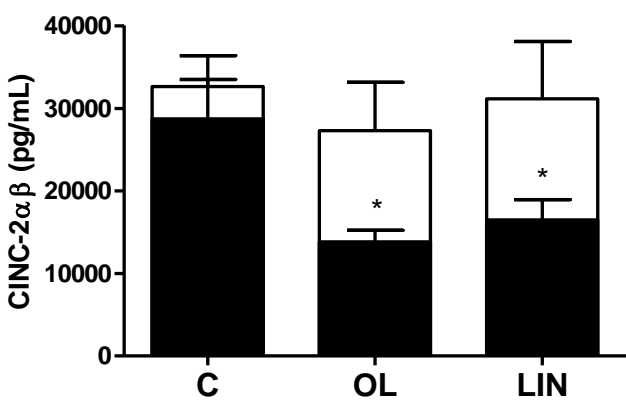

Sem LPS

$\square$ Com LPS

24 horas

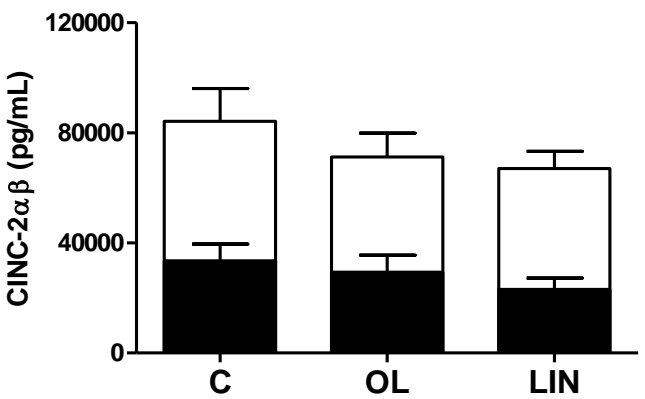

Figura 17. Produção de CINC-2a $\beta$ durante 5 ou $24 \mathrm{~h}$ por macrófagos $\left(10^{6}\right.$ células) isolados do peritônio de ratos suplementados com água $(\mathrm{C})$, ácidos oleico $(\mathrm{OL})$ ou linoleico (LIN) por 10 dias e incubados na ausência ou presença de LPS $(5 \mu \mathrm{g} / \mathrm{mL})$. Os resultados estão apresentados como média \pm EPM de 5 (para incubação de $5 \mathrm{~h}$ ) e no mínimo 8 (para incubação de $24 \mathrm{~h}$ ) amostras independentes. ${ }^{*} p<0,05$, comparado ao controle sem LPS (ANOVA com pós-teste Dunnett).

O tratamento in vitro com os ácidos oleico ou linoleico na ausência de LPS estimulou a produção de VEGF. O tratamento com o ácido oleico nas concentrações de $25 \mu \mathrm{M}, 50 \mu \mathrm{M}$ e $100 \mu \mathrm{M}$ acarretou em aumento de 1,2, 1,3 e 1,4 vezes, respectivamente, e o tratamento com $100 \mu \mathrm{M}$ do ácido linoleico aumentou em 1,2 vezes a produção de VEGF, quando comparados ao controle (Figura 18). Já o 
tratamento in vivo com ácido linoleico reduziu em 32\% a produção de VEGF quando as células foram incubadas por 24 horas, enquanto que não foi observada alteração quando as mesmas foram incubadas por 5 horas. A suplementação com ácido oleico não alterou a produção de VEGF de macrófagos incubados por 5 ou 24 horas (Figura 19). Os dados relativos às células incubadas com LPS não estão mostrados visto que este composto não estimulou a produção de VEGF.
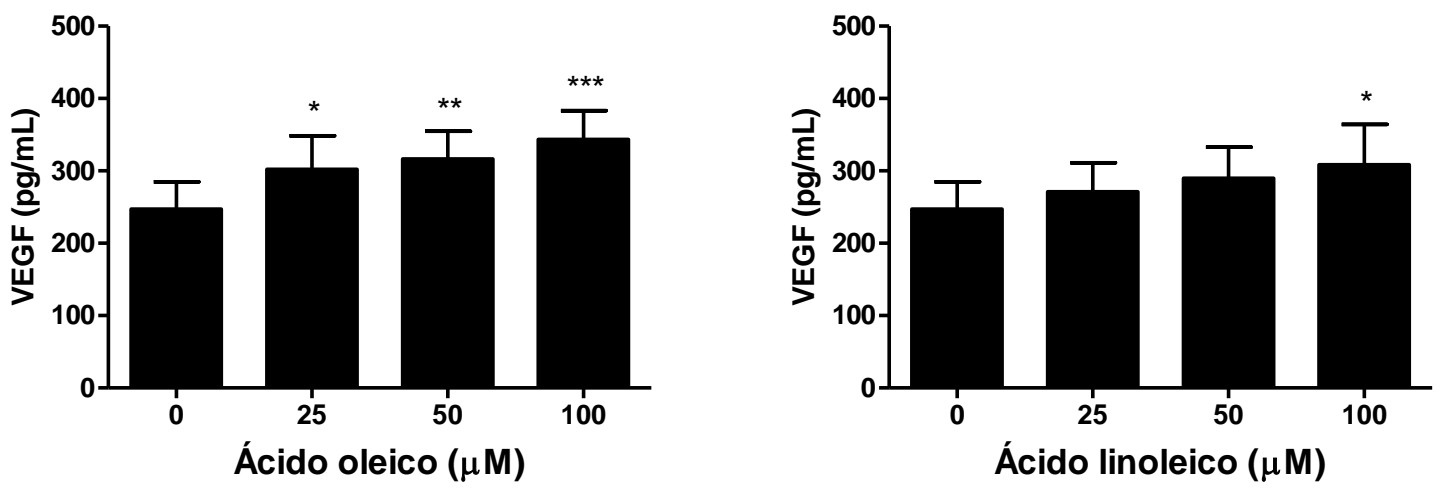

Figura 18. Produção de VEGF por macrófagos $\left(10^{6}\right.$ células), isolados do peritônio de ratos, tratados in vitro com etanol (controle), ácidos oleico ou linoleico $(25 \mu \mathrm{M}, 50 \mu \mathrm{M}, 100 \mu \mathrm{M})$ por $24 \mathrm{~h}$. Os resultados estão apresentados como média \pm EPM de no mínimo 14 amostras independentes. ${ }^{*} p<0,05,{ }^{* *} p<0,01$ e ${ }^{* *} p<0,001$, comparado ao controle (ANOVA pareada com pós-teste Dunnett).

5 horas

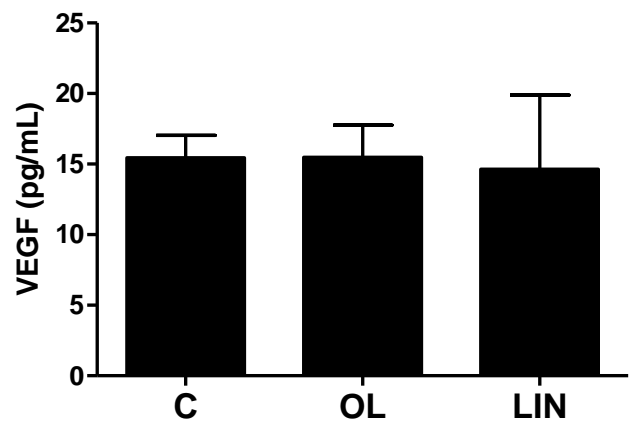

24 horas

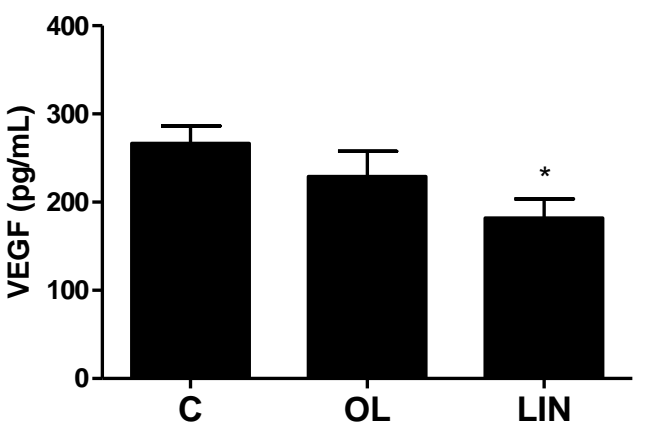

Figura 19. Produção de VEGF durante 5 ou $24 \mathrm{~h}$ por macrófagos $\left(10^{6}\right.$ células) isolados do peritônio de ratos suplementados com água (C), ácidos oleico (OL) ou linoleico (LIN) por 10 dias. Os resultados estão apresentados como média \pm EPM de 5 (para incubação de 5 h) e no mínimo 11 (para incubação de $24 \mathrm{~h}$ ) amostras independentes. * $\mathrm{p}<0,05$, comparado ao controle (ANOVA com pós-teste Dunnett). 


\section{DISCUSSÃO}

Antes de avaliar a produção dos mediadores inflamatórios, foi necessário verificar se o tratamento com os ácidos graxos não era tóxico ao organismo e às células. Em estudo feito pelo grupo (45), foi demonstrado que a suplementação de ratos com os ácidos oleico ou linoleico, nas mesmas condições do presente trabalho, não altera a atividade de enzimas do soro (alanina transaminase, aspartato transaminase e lactato desidrogenase), indicando que não há toxicidade hepática, e tampouco na morfologia do intestino, sugerindo que os ácidos graxos administrados na forma pura não são tóxicos a estes órgãos. Além disso, a suplementação com os ácidos oleico ou linoleico não alterou os parâmetros nutricionais (consumo alimentar e calórico e ingestão de água) e a concentração de ácidos graxos livres no plasma (45).

Já a toxicidade dos ácidos graxos aos macrófagos foi avaliada pela análise da fragmentação de DNA utilizando o fluoróforo iodeto de propídio por citometria de fluxo e a atividade da succinato desidrogenase mitocondrial através do ensaio de MTT. Nas condições utilizadas no presente estudo, os tratamentos in vivo e in vitro não afetaram a fragmentação de DNA em macrófagos peritoneais. Já na análise de MTT, embora a suplementação dos animais não tenha afetado a resposta dos macrófagos, o tratamento in vitro com os ácidos oleico ou linoleico aumentou a absorbância nos ensaios de MTT, sugerindo que o tratamento por $24 \mathrm{~h}$ com os ácidos graxos aumentou a viabilidade dessas células ou a atividade mitocondrial. Como conclusão, os ácidos graxos não foram tóxicos nas condições estudadas.

O primeiro efeito dos ácidos graxos a ser estudado foi na produção de ROS. Tanto a produção de ânion superóxido quanto de peróxido de hidrogênio foram medidas, já que são precursores de metabólitos mais reativos como radical hidroxila e $\mathrm{HOCl}$, além de atuarem como sinalizadores intracelulares $(22,23)$. Não foi observado efeito significativo dos ácidos graxos tratados in vitro sobre a produção de ROS estimulada ou não com PMA através do ensaio de quimiluminescência amplificada por lucigenina. Entretanto, o tratamento in vitro com ácidos oleico ou linoleico, na ausência de PMA, reduziu a produção de peróxido de hidrogênio, de acordo com o ensaio de fluorescência utilizando Amplex ${ }^{\circledR}$ Ultrared. Da mesma forma, 
o tratamento in vitro com ácido oleico reduz a produção de ROS em células microgliais estimuladas com LPS (49), enquanto que, em neutrófilos e linfócitos, a adição de ácidos oleico ou linoleico aumenta a produção de ROS $(46,50)$. Já o ácido araquidônico, ácido graxo n-6 derivado do ácido linoleico, aumenta o burst oxidativo de diversos leucócitos, incluindo macrófagos (51). Entretanto, em todos esses estudos, o meio em que as células estavam ao longo dos ensaios de ROS não continha soro bovino fetal e, portanto, albumina sérica, fazendo com que uma concentração maior de ácidos graxos se encontrasse na forma livre para agir nas células. Além disso, muitas vezes o efeito só foi observado tratando-se as células com altas concentrações (acima de $100 \mu \mathrm{M}$ ) dos ácidos graxos.

Já o tratamento in vivo com os ácidos oleico ou linoleico não interferiu na produção de ROS. Entretanto, já foi demonstrado que o consumo de lipídeos aumenta a produção de ROS em leucócitos. Após $1 \mathrm{~h}$ da ingestão de um creme contendo $33 \mathrm{~g}$ de gordura, sendo $70 \%$ ácidos graxos saturados e $28 \%$ insaturados, PMNs e MNCs apresentam aumento na produção de ROS, a qual é mantida elevada por pelo menos $2 \mathrm{~h}$ (52). Da mesma forma, uma infusão de triglicerídeos aumentando a concentração plasmática de ácido graxo livre acarreta em elevação da produção de ROS em PMNs e MNCs (53). Porém, esses estudos tratam da ingestão aguda, e não crônica, de lipídeos, além do fato de que eram principalmente compostos por ácidos graxos saturados. Já a suplementação por 12 semanas com cápsulas de óleo enriquecido com ácido araquidônico não tem efeito sobre o burst respiratório de neutrófilos e monócitos (54), embora a suplementação com EPA e DHA apresente um efeito supressor (55).

Em seguida, foram analisados os efeitos dos tratamentos in vitro e in vivo com os ácidos oleico ou linoleico na produção de nitrito, citocinas e VEGF, cujos resultados estão resumidos na Tabela 1. 
Tabela 1 - Resumo dos efeitos dos tratamentos in vitro e in vivo com os ácidos oleico ou linoleico na ausência ou presença de LPS.

\begin{tabular}{|c|c|c|c|c|}
\hline & \multicolumn{2}{|c|}{ ÁCIDO OLEICO } & \multicolumn{2}{|c|}{ ÁCIDO LINOLEICO } \\
\hline & Sem LPS & Com LPS & Sem LPS & Com LPS \\
\hline \multicolumn{5}{|l|}{ Nitrito } \\
\hline In vitro & $\Downarrow$ & $\Downarrow$ & $\Downarrow$ & $\Downarrow$ \\
\hline In vivo & $\Leftrightarrow$ & $\Leftrightarrow$ & $\Leftrightarrow$ & $\Leftrightarrow$ \\
\hline \multicolumn{5}{|l|}{ TNF- $\alpha$} \\
\hline In vitro & $\Leftrightarrow$ & $\Downarrow$ & $\Leftrightarrow$ & $\Downarrow$ \\
\hline In vivo & $\Downarrow$ & $\Leftrightarrow$ & $\Downarrow$ & $\Leftrightarrow$ \\
\hline \multicolumn{5}{|l|}{ IL-1 $\beta$} \\
\hline In vitro & $\Leftrightarrow$ & $\Leftrightarrow$ & $\Leftrightarrow$ & $\Leftrightarrow$ \\
\hline In vivo & 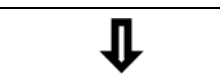 & $\Leftrightarrow$ & $\sqrt{ }$ & $\Leftrightarrow$ \\
\hline \multicolumn{5}{|l|}{ IL-6 } \\
\hline In vitro & $\boldsymbol{1}$ & $\uparrow$ & $\Leftrightarrow$ & $\Leftrightarrow$ \\
\hline In vivo & $\Downarrow$ & $\Leftrightarrow$ & $\Downarrow$ & $\Leftrightarrow$ \\
\hline
\end{tabular}

\section{CINC-2 $\alpha \beta$}

\begin{tabular}{|c|c|c|c|c|}
\hline In vitro & $\boldsymbol{1}$ & $\Leftrightarrow$ & 1 & $\Leftrightarrow$ \\
\hline In vivo & $\Downarrow$ & $\Leftrightarrow$ & $\downarrow$ & $\Leftrightarrow$ \\
\hline \multicolumn{5}{|l|}{ VEGF } \\
\hline In vitro & 1 & $\uparrow$ & $\uparrow$ & $\uparrow$ \\
\hline In vivo & $\Leftrightarrow$ & $\Leftrightarrow$ & $\Downarrow$ & $\Leftrightarrow$ \\
\hline
\end{tabular}

\: aumento $\mathbb{V}$ : redução

O tratamento in vitro com os ácidos oleico ou linoleico reduziu a produção de nitrito estimulada ou não por LPS. Entretanto, nenhum efeito foi observado com a suplementação desses ácidos graxos. A quantificação de nitrito é uma medida indireta da produção de óxido nítrico, já que é derivado deste composto e representa uma das RNS. Em macrófagos, a produção de óxido nítrico é catalisada principalmente pela iNOS, a qual é ativada por citocinas ou produtos bacterianos. 
Além de essenciais para a atividade microbicida, as RNS modulam vários eventos da resposta imune: apoptose, diferenciação e proliferação de linfócitos, síntese de citocinas, moléculas de adesão e componentes da matriz extracelular. Podem, entretanto, também estar associadas a citotoxicidade e danos teciduais (20).

Resultados similares ao tratamento in vitro foram encontrados em estudo realizado com a linhagem murina de macrófagos RAW 264.7. O tratamento por $20 \mathrm{~h}$ com $100 \mu \mathrm{M}$ dos ácidos linoleico ou araquidônico na presença de LPS reduz a produção de nitrito, o que não é acompanhado por alteração na expressão de iNOS (56). Além disso, o tratamento desta linhagem de células por $12 \mathrm{~h}$ com ácido linoleico, na presença de LPS, reduz a produção de nitrito na presença de $20 \mu \mathrm{M}$, mas não de $100 \mu \mathrm{M}$ (57). Entretanto, em linhagem de macrófagos murinos $\mathrm{J774}$ tratada por $48 \mathrm{~h}$ com diferentes concentrações (1-100 $\mu \mathrm{M})$ dos ácidos oleico ou linoleico na presença de LPS, observa-se aumento na produção de nitrito. Quando em concentração de 2,5 $\mu \mathrm{M}$, observa-se maior expressão de iNOS após $12 \mathrm{~h}$ de tratamento para o ácido oleico e 6, 12 e 24 h para o ácido linoleico. No caso do ácido oleico, sugere-se que este aumento na expressão ocorre por ativação do NFKB (58). O efeito observado para o tratamento de $24 \mathrm{~h}$ com ácido linoleico na presença de LPS parece ser abolido quando IFN-Y é adicionado ao meio de cultura (59).

Possivelmente, resultados conflitantes encontrados nos estudos são devido aos diferentes modelos de macrófagos ou às diferenças nos períodos de tratamento com os ácidos graxos, ou seja, as células só aumentam a produção de nitrito se tratadas com ácido graxo por um período maior que $24 \mathrm{~h}$. Os ácidos graxos podem alterar as funções dos macrófagos de diversas formas. Uma delas é modificando a composição dos fosfolipídios presentes na membrana plasmática, o que afeta diferentes vias de sinalização (38). O tratamento in vitro por $24 \mathrm{~h}$ de macrófagos peritoneais de ratos com fosfatidilcolina (uma classe de fosfolipídios) rica em ácido linoleico, na presença de LPS, diminui a produção de nitrito (48), sugerindo um possível mecanismo de ação dos ácidos graxos no presente estudo.

A suplementação de camundongos por 8 semanas com óleo de oliva ou de açafrão, ricos em ácidos oleico e linoleico, respectivamente, aumenta a produção de nitrito por macrófagos estimulados por LPS (60), enquanto que a suplementação por 
16 semanas com os mesmos óleos reduz a produção deste (61). Além disso, macrófagos peritoneais de camundongos tratados por 16 semanas com óleo de milho, rico em ácido linoleico, produzem significativamente menos nitrito que aqueles de camundongos tratados com óleo de oliva, quando estimulados por PMA (62). fato de em nosso estudo não termos encontrado alteração na produção de nitrito em macrófagos de ratos suplementados por 10 dias com ácidos oleico ou linoleico pode ser decorrente da diferença no período de tratamento entre os estudos, nas quantidades ingeridas ou no fato de haver nos óleos outros compostos que, independentemente do ácido graxo, influenciam a função de macrófagos.

Durante o processo inflamatório, diversas citocinas são secretadas por macrófagos e outras células em decorrência da ativação de PRRs presentes em suas membranas por componentes e/ou produtos de microrganismos ou células necrosadas. O TNF- $\alpha$ é uma das primeiras citocinas a ser secretada na resposta inflamatória e desencadeia uma série de reações no organismo, incluindo ativação e migração de leucócitos para o foco inflamatório. Essa citocina também regula a proliferação, diferenciação e apoptose celular. Sua importância é demonstrada em camundongos deficientes para o TNF ou seu receptor, os quais apresentam susceptibilidade aumentada ao desenvolvimento de infecções por diferentes microorganismos. Entretanto, em altas concentrações no organismo, esta citocina pode acarretar em inflamação crônica e até choque séptico $(63,64)$.

Em nosso estudo, foi verificado que o tratamento in vitro por $24 \mathrm{~h}$ com os ácidos oleico ou linoleico diminuiu o efeito estimulatório do LPS na produção de TNF-a, enquanto que os ácidos graxos não apresentaram qualquer efeito sobre a produção desse mediador inflamatório na ausência de LPS. A mesma resposta ao tratamento com os ácidos graxos na presença de LPS foi recentemente observada em estudo realizado com linhagem de macrófagos murinos $\mathbf{J 7 7 4}$, embora neste 0 tratamento apenas com $50 \mu \mathrm{M}$ do ácido oleico tenha aumentado a produção de TNF-a (65). Outros autores também mostraram que a produção desta citocina é reduzida quando macrófagos peritoneais cuja migração foi induzida por tioglicolato são incubados com ácido linoleico (66) e macrófagos da linhagem RAW 264.7 estimulados por IFN-y e tratados in vitro com o mesmo ácido graxo (67). 
A expressão de TNF- $\alpha$ é inibida por altas concentrações de $\mathrm{PGE}_{2}(68,69)$. A $\mathrm{PGE}_{2}$ é produzida a partir de ácido araquidônico e este é derivado do ácido linoleico. A diminuição na concentração de TNF-a pelo tratamento in vitro com ácido linoleico encontrada neste estudo poderia ser explicada por um aumento nas concentrações de ácido araquidônico na membrana plasmática, o que pode aumentar a síntese de $\mathrm{PGE}_{2}$. Entretanto, isso é ainda controverso, já que o aumento na ingestão de ácido linoleico só altera as concentrações de ácido araquidônico em condição de deficiência de ácidos graxos essenciais (70). Além disso, ácidos graxos insaturados, como oleico e linoleico, não induzem em macrófagos a expressão da COX-2, enzima que catalisa a conversão de ácido araquidônico a $\mathrm{PGH}_{2}$, precursora das outras prostaglandinas (71). Por outro lado, a diminuição na concentração de TNF-a após $24 \mathrm{~h}$ de tratamento com os ácidos graxos pode ser reflexo de um estímulo rápido para a produção desta citocina. Esta última hipótese parece mais plausível, já que o tratamento in vitro com os ácidos oleico ou linoleico aumentou a expressão de outras citocinas deste estudo.

Só foi observada redução na produção de TNF-a quando macrófagos isolados de ratos suplementados com os ácidos oleico ou linoleico foram incubados por 5 horas, na ausência de LPS. Possivelmente, este efeito deixou de ser observado após 24 horas de incubação porque o TNF-a é uma citocina cujo gene é rapidamente expresso, demonstrado pela menor concentração desta citocina no grupo controle após 24 horas de incubação, quando comparado ao mesmo grupo porém após 5 horas de incubação. Sugere-se então que, ao longo do tempo, começou a haver degradação desta citocina, dificultando a identificação do efeito do tratamento in vivo sobre sua produção. Semelhantemente, a suplementação de camundongos por 6 ou 8 semanas com óleo de oliva ou de açafrão diminui a secreção de TNF- $\alpha$ por macrófagos peritoneais induzidos por tioglicolato estimulados com LPS $(60,61,72)$. Deve ser levado em consideração, entretanto, o estado de ativação das células, visto que macrófagos residentes do peritônio estimulados por LPS não apresentam alteração na produção de TNF-a quando tratados com os mesmos óleos (72).

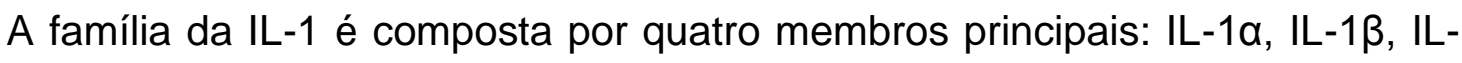
1ra e IL-18. Essas citocinas são mediadores importantes da inflamação já que estimulam vias de sinalização que resultam em aumento da transcrição de genes 
que codificam outras citocinas, quimiocinas, moléculas de adesão, proteínas de fase aguda e proteases. A IL-1 $\alpha$ e a IL-1 $\beta$ são produzidas por vários tipos de células, mas principalmente por monócitos e macrófagos. Ambas são produzidas a partir de suas formas imaturas, pró-IL-1 $\alpha$ e pró-IL-1 $\beta$, que são clivadas pela calpaína ou caspase-1, respectivamente, originando suas formas maduras. A pró-IL-1 $\alpha$ é tão ativa quanto a IL-1 $\alpha$ e pode ser encontrada intracelularmente ou na superfície de diversas células como monócitos e linfócitos $B$. Já a pró-IL-1 $\beta$ permanece inativa no citossol até ser clivada e transportada para fora da célula $(73,74)$.

O tratamento in vitro com ácidos oleico ou linoleico, na ausência ou presença de LPS, não alterou a liberação de IL-1 $\beta$ pelos macrófagos residentes de ratos. $O$ mesmo resultado foi observado em células humanas THP-1 diferenciadas em macrófagos tratadas com ácido linoleico, com ou sem LPS (75). Do mesmo modo, a suplementação com ácidos oleico ou linoleico não alterou a secreção desta citocina por macrófagos estimulados com LPS, o que está de acordo com outros estudos utilizando óleo de oliva ou de açafrão $(60,72)$. Nosso estudo é o primeiro a demonstrar um efeito supressor do tratamento in vivo com ácidos oleico ou linoleico na secreção basal de IL-1 $\beta$. No caso do ácido linoleico, este efeito foi observado já a partir de 5 horas de incubação.

Além de TNF- $\alpha$ e IL-1 $\beta$, macrófagos residentes também produzem IL- 6 em resposta ao reconhecimento de micro-organismos invasores, e juntos modulam a resposta inflamatória local e sistêmica (76). Dentre as ações da IL-6, vale ressaltar a síntese de proteínas de fase aguda pelos hepatócitos, modulação da proliferação e diferenciação de linfócitos $T$ citotóxicos, indução da produção de anticorpos por linfócitos B e estimulação da resolução da inflamação, sendo esse último efeito, ao menos em parte, decorrente das ações dessa citocinas sobre a apoptose e a síntese de quimiocinas. Além disso, a superprodução de IL-6 está associada com o desenvolvimento de doenças inflamatórias crônicas e autoimunes, como doença de Crohn, doença de Castleman, mieloma múltiplo e artrite reumatoide $(77,78)$.

Neste estudo, a IL-6 foi a única citocina cuja produção foi modulada diferentemente pelo tratamento in vitro com os ácidos oleico ou linoleico. $O$ ácido oleico, na ausência e presença de LPS, aumentou a secreção desta citocina, enquanto que $\mathrm{o}$ ácido linoleico não apresentou efeito. Embora haja inúmeros 
estudos demonstrando efeito supressor pelo tratamento in vitro $(79,80)$ e in vivo $(81$ 83) com DHA e EPA na produção desta citocina em macrófagos, não foi verificado efeito in vitro dos ácidos oleico ou linoleico. Por outro lado, o tratamento in vivo com ácidos oleico ou linoleico reduziu a produção de IL-6 na ausência de LPS. Este efeito de inibição foi observado após 5 horas de incubação das células, porém só foi mantido por 24 horas nas células dos animais tratados com ácido linoleico. Aparentemente, o ácido oleico atrasou a síntese de IL-6, já que a concentração desta citocina no grupo controle e no tratado com ácido linoleico é semelhante entre as células incubadas por 5 ou 24 horas, porém é aumentada e similar ao controle no grupo tratado com ácido oleico após 24 horas de incubação.

A liberação de citocinas como TNF- $\alpha$, IL-1 e IL-6 no foco inflamatório estimula a expressão de quimiocinas (84). Estas podem ser divididas em quatro grupos de acordo com o número de resíduos de aminoácidos entre os dois primeiros resíduos de cisteínas: $\mathrm{CC}, \mathrm{CXC}, \mathrm{CX}_{3} \mathrm{C}$ e $\mathrm{XC}$, sendo as quimiocinas $\mathrm{CXC}$ os principais agentes quimioatraentes de neutrófilos durante a inflamação. Células que expressam os receptores para quimiocinas, leucócitos no caso da resposta inflamatória, são atraídas para os locais com maior concentração dos quimioatraentes. A imobilização das quimiocinas no foco inflamatório e nas células endoteliais dos vasos sanguíneos locais é um passo importante para assegurar a migração dos leucócitos e é obtida através da interação de suas formas oligoméricas com receptores da superfície celular e glicosaminoglicanos $(85,86)$.

Nosso estudo é o primeiro a demonstrar o efeito estimulatório do tratamento in vitro com ácidos oleico e linoleico, na ausência de LPS, na produção de CINC$2 \alpha \beta / C X C L 3$ por macrófagos. Nosso grupo já havia demonstrado um efeito similar em neutrófilos, quando incubados in vitro com ácido oleico por $18 \mathrm{~h}$ (87). Em macrófagos U937, a adição de ácidos oleico, linoleico ou araquidônico não altera a produção de IP-10/CXCL10, enquanto que o ácido palmítico aumenta sua expressão (88). Possivelmente, o efeito estimulatório do tratamento in vitro foi independente da indução por outras citocinas, já que tanto TNF- $\alpha$ quanto IL-1ß não estavam em concentrações aumentadas no sobrenadante das células tratadas com os ácidos graxos, a não ser que a diminuição na concentração de TNF- $\alpha$ seja reflexo de um aumento inicial em sua produção. 
O tratamento in vivo com os ácidos oleico ou linoleico reduziu a produção basal de CINC-2a $\beta$ de macrófagos incubados por 5 horas. Entretanto, este efeito atenuou-se até 24 horas de incubação, já que neste momento as concentrações desta quimiocina se encontravam similares às do controle. Não há estudos verificando o efeito da suplementação com esses ácidos graxos na produção de quimiocinas por macrófagos. Entretanto, nosso grupo demonstrou que neutrófilos de ratos suplementados com ácido linoleico apresentam produção de CINC-2 $\alpha \beta$ mais elevada que o controle após 4 horas de incubação e uma redução na sua secreção após 18 horas de incubação (45).

A resolução da inflamação e o início do reparo tecidual dependem, dentre outros fatores, da secreção de VEGF, fator de crescimento promotor da angiogênese, possibilitando o aporte de nutrientes e oxigênio para o tecido. O VEGF é secretado principalmente por macrófagos e queratinócitos em resposta à hipóxia e age nas células endoteliais de vasos sanguíneos locais. A partir daí, as células endoteliais proliferam e migram na direção da fonte do sinal, estabelecendo então a neovascularização. Por estimular a formação de novos vasos sanguíneos, sua produção precisa ser controlada, já que altas concentrações podem acarretar em fibrose e câncer $(31,89,90)$.

Esta é a primeira vez em que foi estudado o efeito de ácidos graxos na produção de VEGF por macrófagos. Os ácidos oleico e linoleico, in vitro, aumentaram a produção deste fator de crescimento em macrófagos. Esses ácidos graxos também aumentam a síntese de VEGF em neutrófilos de ratos (87). Entretanto, o tratamento in vivo com o ácido linoleico reduziu a produção basal deste fator de crescimento após 24 horas de incubação. Possivelmente, este efeito não foi observado com menor período de incubação pois o VEGF é uma proteína que atinge altas concentrações somente após um certo período de incubação, como observado pelo aumento de mais de 15 vezes entre 5 e 24 horas. Já a suplementação com ácido oleico não alterou produção de VEGF.

O mecanismo de ação pelo qual os ácidos graxos modificaram os parâmetros funcionais de macrófagos ainda é incerto. No caso dos tratamentos in vitro, eles apresentaram em geral um efeito pró-inflamatório, aumentaram a produção de IL-6, CINC-2 $\alpha \beta$ e VEGF e reduziram a produção de TNF- $\alpha$ e nitrito após $24 \mathrm{~h}$ de 
incubação, sendo que esses últimos resultados podem ter sido decorrentes de um efeito estimulatório inicial, como já discutido. Um dos possíveis mecanismos de ação dos ácidos graxos é através da ativação de fatores de transcrição. O efeito próinflamatório de ácidos graxos ocorre através da ativação do NF-kB e AP-1, os quais induzem a transcrição de diversos genes relacionados à resposta inflamatória (88, 91, 92). Entretanto, estes estudos estão limitados a outros modelos celulares ou ácidos graxos saturados. Os autores que empregaram macrófagos e tratamento in vitro com ácidos graxos insaturados, embora com diferenças no modelo celular, concentração de ácido graxo e design experimental, evidenciam que há menor ativação destes fatores de transcrição com consequente redução nas concentrações de citocinas $(93,94)$, ou seja, diferente dos achados do presente estudo, sendo assim necessárias mais investigações para compreender estes resultados.

O tratamento dos animais com os mesmos ácidos graxos desencadeou uma resposta diferente nos macrófagos. De maneira geral, nossos resultados são sugestivos de que eles são agentes anti-inflamatórios, já que diminuíram significativamente as concentrações de TNF- $\alpha$, IL-1 $1 \beta$, IL-6, CINC-2 $\alpha \beta$ e VEGF. As diferenças encontradas entre os tratamentos in vitro e in vivo indicam que os macrófagos estão sofrendo influência de outros fatores além dos próprios ácidos oleico ou linoleico. Essa influência pode ter sido originada de outras células cuja biologia também é modificada pelo tratamento in vivo com ácidos graxos, como já verificado em neutrófilos (45), linfócitos (95), tecido adiposo (96), entre outros. Assim, a alteração na síntese e secreção de metabólitos dessas células afetaria a função dos macrófagos.

Outra hipótese para explicar tais diferenças seria a de que os ácidos oleico e linoleico foram metabolizados no organismo gerando metabólitos até mesmo outros ácidos graxos. Uma dieta rica em ácidos graxos monoinsaturados reduz as concentrações de ácidos graxos saturados enquanto aumenta as de poli-insaturados nos triacilgliceróis séricos (97). Após serem absorvidos pelos enterócitos, parte desses ácidos graxos formam moléculas de triacilglicerol que, sob a forma de quilomícrons, são secretadas das células e transportadas via ducto torácico (sistema linfático) para o sangue venoso circulante através da veia subclávia. Outra parte é transportada em sua forma livre pelo sistema linfático ou entra na circulação sanguínea via veia porta (98). Os quilomícrons, ao entrar na circulação, sofrem 
hidrólise de seus triacilgliceróis pela atividade da lipase de lipoproteína, presente em diversos tecidos extra-hepáticos, como tecido adiposo e muscular, coração e macrófagos, liberando ácidos graxos livres e glicerol para essas células (99). Os quilomícrons remanescentes, com depleção de aproximadamente $85 \%$ de seus triacilgliceróis, são então removidos da circulação pelos hepatócitos através de endocitose, após ligação com receptores de LDL, e posteriormente digeridos em lisossomos $(100,101)$. Nos hepatócitos, ácidos graxos formam novas moléculas de triacilglierol, que se juntam a apolipoproteínas e ésteres de colesterol para formar moléculas de VLDL, que são transportadas pela circulação sanguínea (102). Os ácidos graxos dos hepatócitos podem ser derivados de quatro fontes: lipogênese de novo, estoques de triacilglicerol citoplasmáticos, triacilgliceróis presentes em lipoproteínas, ou plasma, quando liberados pelo tecido adiposo na forma de ácido graxo livre (103). Além de se agregarem em lipoproteínas, os ácidos graxos podem sofrer oxidação, dessaturação e elongação no fígado. Além disso, a natureza química dos ácidos graxos, comprimento da cadeia e número de insaturações, tem grande influência em tais processos. Por exemplo, o ácido oleico estimula a secreção de VLDL, enquanto que o EPA e o DHA atenuam tal processo (102). O ácido oleico é também um ácido graxo que é rapidamente oxidado (104). Por outro lado, a suplementação com óleo de girassol diminui a concentração de triacilglicerol no fígado e no plasma (105). 


\section{CONCLUSÃO}

Os ácidos oleico e linoleico modulam a função de macrófagos e efeitos diferentes são observados se o tratamento é realizado por suplementação oral de animais ou por adição in vitro. Nas condições estudadas, os ácidos oleico e linoleico, em geral, apresentaram efeitos pró-inflamatórios in vitro e anti-inflamatórios in vivo. Essas diferenças observadas podem ser explicadas por duas hipóteses, não excludentes, que exigem estudos futuros para serem confirmadas. Primeiramente, o ambiente em que os macrófagos estão inseridos nos animais pode ser determinante para sua resposta. Assim, os efeitos que os ácidos graxos podem ter em outras células do organismo influenciam na biologia dos macrófagos ali presentes. Em segundo lugar, os ácidos graxos podem ser convertidas em outras moléculas e, dessa forma, a resposta das células é diferente. Os resultados são sugestivos de que não se pode inferir que observações in vitro podem ser extrapoladas para efeitos biológicos in vivo. Além disso, nosso estudo traz importantes contribuições para o conhecimento dos efeitos dos ácidos oleico e linoleico em diversas funções de macrófagos, como produção de ROS, RNS, citocinas e VEGF, sugerindo que podem ser utilizados como agentes terapêuticos em patologias nas quais essas células estão envolvidas. 


\section{REFERÊNCIAS*}

1. Moser M, Leo O. Key concepts in immunology. Vaccine. 2010 Aug 31;28 (Suppl 3):C2-13.

2. Metchnikoff E. On the Present State of the Question of Immunity in InfectiousDiseases. Scand J Immunol. 1989 Oct;30(4):387-98.

3. Gordon S. The macrophage: past, present and future. Eur J Immunol. 2007 Nov;37 (Suppl 1):S9-17.

4. Dalton DK, Pitts-Meek S, Keshav S, Figari IS, Bradley A, Stewart TA. Multiple defects of immune cell function in mice with disrupted interferon-gamma genes. Science. 1993 Mar 19;259(5102):1739-42.

5. MacMicking J, Xie QW, Nathan C. Nitric oxide and macrophage function. Annu Rev Immunol. 1997;15:323-50.

6. Nimmerjahn F, Ravetch JV. Fcgamma receptors: old friends and new family members. Immunity. 2006 Jan;24(1):19-28.

7. Roozendaal R, Carroll MC. Emerging patterns in complement-mediated pathogen recognition. Cell. 2006 Apr 7;125(1):29-32.

8. Taylor PR, Martinez-Pomares L, Stacey M, Lin HH, Brown GD, Gordon S. Macrophage receptors and immune recognition. Annu Rev Immunol. 2005;23:90144.

9. Janeway CA, Medzhitov R. Innate immune recognition. Annual Review of Immunology. 2002;20:197-216.

10. van Furth R, Cohn ZA. The origin and kinetics of mononuclear phagocytes. J Exp Med. 1968 Sep 1;128(3):415-35.

11. Van Furth R, Diesselhoff-den Dulk MC, Mattie H. Quantitative study on the production and kinetics of mononuclear phagocytes during an acute inflammatory reaction. J Exp Med. 1973 Dec 1;138(6):1314-30. 
12. Serbina NV, Jia T, Hohl TM, Pamer EG. Monocyte-mediated defense against microbial pathogens. Annu Rev Immunol. 2008;26:421-52.

13. Geissmann F, Manz MG, Jung S, Sieweke MH, Merad M, Ley K. Development of monocytes, macrophages, and dendritic cells. Science. 2010 Feb 5;327(5966):656-61.

14. Medzhitov R. Origin and physiological roles of inflammation. Nature. 2008 Jul $24 ; 454(7203): 428-35$.

15. Soehnlein O, Lindbom L. Phagocyte partnership during the onset and resolution of inflammation. Nat Rev Immunol. 2010 Jun;10(6):427-39.

16. Takeuchi $\mathrm{O}$, Akira S. Pattern recognition receptors and inflammation. Cell. 2010 Mar 19;140(6):805-20.

17. Kaplanski G, Marin V, Montero-Julian F, Mantovani A, Farnarier C. IL-6: a regulator of the transition from neutrophil to monocyte recruitment during inflammation. Trends Immunol. 2003 Jan;24(1):25-9.

18. Silva MT. When two is better than one: macrophages and neutrophils work in concert in innate immunity as complementary and cooperative partners of a myeloid phagocyte system. J Leukoc Biol. 2010 Jan;87(1):93-106.

19. Yang HC, Cheng ML, Ho HY, Chiu DT. The microbicidal and cytoregulatory roles of NADPH oxidases. Microbes Infect. 2011 Feb;13(2):109-20.

20. Bogdan C. Nitric oxide and the immune response. Nat Immunol. 2001 Oct;2(10):907-16.

21. Bylund J, Brown KL, Movitz C, Dahlgren C, Karlsson A. Intracellular generation of superoxide by the phagocyte NADPH oxidase: how, where, and what for? Free Radic Biol Med. 2010 Dec 15;49(12):1834-45.

22. Babior BM. NADPH oxidase. Curr Opin Immunol. 2004 Feb;16(1):42-7.

23. Chen K, Craige SE, Keaney JF, Jr. Downstream targets and intracellular compartmentalization in Nox signaling. Antioxid Redox Signal. 2009 Oct;11(10):2467-80. 
24. Umansky V, Hehner SP, Dumont A, Hofmann TG, Schirrmacher V, Droge W, et al. Co-stimulatory effect of nitric oxide on endothelial NF-kappaB implies a physiological self-amplifying mechanism. Eur J Immunol. 1998 Aug;28(8):2276-82.

25. Connelly L, Palacios-Callender M, Ameixa C, Moncada S, Hobbs AJ. Biphasic regulation of NF-kappa $B$ activity underlies the pro- and anti-inflammatory actions of nitric oxide. J Immunol. 2001 Mar 15;166(6):3873-81.

26. Erwig LP, Henson PM. Clearance of apoptotic cells by phagocytes. Cell Death Differ. 2008 Feb;15(2):243-50.

27. Serhan CN, Chiang N, Van Dyke TE. Resolving inflammation: dual antiinflammatory and pro-resolution lipid mediators. Nat Rev Immunol. 2008 May;8(5):349-61.

28. Huynh ML, Fadok VA, Henson PM. Phosphatidylserine-dependent ingestion of apoptotic cells promotes TGF-beta1 secretion and the resolution of inflammation. J Clin Invest. 2002 Jan;109(1):41-50.

29. Kennedy AD, DeLeo FR. Neutrophil apoptosis and the resolution of infection. Immunol Res. 2009;43(1-3):25-61.

30. Nathan C, Ding A. Nonresolving inflammation. Cell. 2010 Mar 19;140(6):87182.

31. Laskin DL, Sunil VR, Gardner CR, Laskin JD. Macrophages and tissue injury: agents of defense or destruction? Annu Rev Pharmacol Toxicol. 2011 Feb $10 ; 51: 267-88$.

32. Kumar V, Robbins SL. Robbins basic pathology. 8th ed. Philadelphia: Saunders/Elsevier; 2007.

33. Berg JM, Tymoczko JL, Stryer L. Biochemistry. 5th ed. New York: W. H. Freeman and Co.; 2002.

34. Lehninger AL, Nelson DL, Cox MM. Lehninger principles of biochemistry. 4 ed. New York: W. H. Freeman; 2005.

35. Guyton AC, Hall JE. Textbook of medical physiology. 11th ed. Edinburgh: Elsevier/Saunders; 2006. 
36. Martins de Lima T, Gorjao R, Hatanaka E, Cury-Boaventura MF, Portioli Silva EP, Procopio J, et al. Mechanisms by which fatty acids regulate leucocyte function. Clin Sci (Lond). 2007 Jul;113(2):65-77.

37. Huwiler A, Pfeilschifter J. Lipids as targets for novel anti-inflammatory therapies. Pharmacol Ther. 2009 Oct;124(1):96-112.

38. Calder PC, Grimble RF. Polyunsaturated fatty acids, inflammation and immunity. Eur J Clin Nutr. 2002 Aug;56 (Suppl 3):S14-9.

39. Piette M, Saugier J. [Effect of the intravenous infusion of a lipid emulsion on blood leukocytes in the rabbit]. Ann Pharm Fr. 1970 Sep-Oct;28(9):529-34.

40. Galli C, Calder PC. Effects of fat and fatty acid intake on inflammatory and immune responses: a critical review. Ann Nutr Metab. 2009;55(1-3):123-39.

41. Calder PC. Polyunsaturated fatty acids, inflammatory processes and inflammatory bowel diseases. Mol Nutr Food Res. 2008 Aug;52(8):885-97.

42. Yaqoob P. Monounsaturated fatty acids and immune function. Eur $\mathrm{J}$ Clin Nutr. 2002 Aug;56 Suppl 3:S9-S13.

43. Nutrient Intakes from Food: Mean Amounts Consumed per Individual, by Gender and Age, What We Eat in America, NHANES 2007-2008 [database on the Internet]. U.S. Department of Agriculture, Agricultural Research Service. 2010. Available from: www.ars.usda.gov/ba/bhnrc/fsrg. [2011 June 27].

44. Unsaturated fatty acids: nutritional and physiological significance (British Nutrition Foundation Task Force Reports Series). London: Chapman \& Hall; 1992.

45. Rodrigues HG, Vinolo MA, Magdalon J, Fujiwara $\mathrm{H}$, Cavalcanti DM, Farsky $\mathrm{SH}$, et al. Dietary free oleic and linoleic acid enhances neutrophil function and modulates the inflammatory response in rats. Lipids. 2010 Sep;45(9):809-19.

46. Hatanaka E, Levada-Pires AC, Pithon-Curi TC, Curi R. Systematic study on ROS production induced by oleic, linoleic, and gamma-linolenic acids in human and rat neutrophils. Free Radic Biol Med. 2006 Oct 1;41(7):1124-32.

47. Zhou M, Diwu Z, Panchuk-Voloshina N, Haugland RP. A stable nonfluorescent derivative of resorufin for the fluorometric determination of trace hydrogen peroxide: applications in detecting the activity of phagocyte NADPH oxidase and other oxidases. Anal Biochem. 1997 Nov 15;253(2):162-8. 
48. Grando FC, Felicio CA, Twardowschy A, Paula FM, Batista VG, Fernandes LC, et al. Modulation of peritoneal macrophage activity by the saturation state of the fatty acid moiety of phosphatidylcholine. Braz J Med Biol Res. 2009 Jul;42(7):599605.

49. Oh YT, Lee JY, Lee J, Kim H, Yoon KS, Choe W, et al. Oleic acid reduces lipopolysaccharide-induced expression of iNOS and COX-2 in BV2 murine microglial cells: possible involvement of reactive oxygen species, p38 MAPK, and IKK/NFkappaB signaling pathways. Neurosci Lett. 2009 Oct 23;464(2):93-7.

50. Cury-Boaventura MF, Curi R. Regulation of reactive oxygen species (ROS) production by $\mathrm{C} 18$ fatty acids in Jurkat and Raji cells. Clin Sci (Lond). 2005 Mar;108(3):245-53.

51. Pompeia C, Cury-Boaventura MF, Curi R. Arachidonic acid triggers an oxidative burst in leukocytes. Braz J Med Biol Res. 2003 Nov;36(11):1549-60.

52. Mohanty P, Ghanim H, Hamouda W, Aljada A, Garg R, Dandona P. Both lipid and protein intakes stimulate increased generation of reactive oxygen species by polymorphonuclear leukocytes and mononuclear cells. American Journal of Clinical Nutrition. 2002 Apr;75(4):767-72.

53. Tripathy D, Mohanty $P$, Dhindsa $S$, Syed $T$, Ghanim H, Aljada A, et al. Elevation of free fatty acids induces inflammation and impairs vascular reactivity in healthy subjects. Diabetes. 2003 Dec;52(12):2882-7.

54. Thies F, Miles EA, Nebe-von-Caron G, Powell JR, Hurst TL, Newsholme EA, et al. Influence of dietary supplementation with long-chain n-3 or n-6 polyunsaturated fatty acids on blood inflammatory cell populations and functions and on plasma soluble adhesion molecules in healthy adults. Lipids. 2001 Nov;36(11):1183-93.

55. Calder PC. n-3 polyunsaturated fatty acids, inflammation, and inflammatory diseases. Am J Clin Nutr. 2006 Jun;83(6 Suppl):1505S-19S.

56. Ambrozova G, Pekarova M, Lojek A. Effect of polyunsaturated fatty acids on the reactive oxygen and nitrogen species production by raw 264.7 macrophages. Eur J Nutr. 2010 Apr;49(3):133-9.

57. Murakami A, Nishizawa T, Egawa K, Kawada T, Nishikawa Y, Uenakai K, et al. New class of linoleic acid metabolites biosynthesized by corn and rice lipoxygenases: suppression of proinflammatory mediator expression via attenuation of MAPK- and Akt-, but not PPARgamma-, dependent pathways in stimulated macrophages. Biochem Pharmacol. 2005 Nov 1;70(9):1330-42. 
58. de Lima TM, de Sa Lima L, Scavone C, Curi R. Fatty acid control of nitric oxide production by macrophages. FEBS Lett. 2006 May 29;580(13):3287-95.

59. Komatsu W, Ishihara K, Murata M, Saito H, Shinohara K. Docosahexaenoic acid suppresses nitric oxide production and inducible nitric oxide synthase expression in interferon-gamma plus lipopolysaccharide-stimulated murine macrophages by inhibiting the oxidative stress. Free Radic Biol Med. 2003 Apr 15;34(8):1006-16.

60. Yaqoob $P$, Calder $P$. Effects of dietary lipid manipulation upon inflammatory mediator production by murine macrophages. Cell Immunol. 1995 Jun;163(1):120-8.

61. Wallace FA, Neely SJ, Miles EA, Calder PC. Dietary fats affect macrophagemediated cytotoxicity towards tumour cells. Immunol Cell Biol. 2000 Feb;78(1):40-8.

62. Moreno JJ, Carbonell T, Sanchez T, Miret S, Mitjavila MT. Olive oil decreases both oxidative stress and the production of arachidonic acid metabolites by the prostaglandin $\mathrm{G} / \mathrm{H}$ synthase pathway in rat macrophages. Journal of Nutrition. 2001 Aug;131(8):2145-9.

63. Tracey KJ, Cerami A. Tumor necrosis factor: an updated review of its biology. Crit Care Med. 1993 Oct;21(10 Suppl):S415-22.

64. Locksley RM, Killeen N, Lenardo MJ. The TNF and TNF receptor superfamilies: integrating mammalian biology. Cell. 2001 Feb 23;104(4):487-501.

65. de Lima-Salgado TM, Alba-Loureiro TC, do Nascimento CS, Nunes MT, Curi R. Molecular Mechanisms by Which Saturated Fatty Acids Modulate TNF-alpha Expression in Mouse Macrophage Lineage. Cell Biochem Biophys. 2011 Mar;59(2):89-97.

66. Tappia PS, Man WJ, Grimble RF. Influence of unsaturated fatty acids on the production of tumour necrosis factor and interleukin- 6 by rat peritoneal macrophages. Mol Cell Biochem. 1995 Feb 23;143(2):89-98.

67. $\mathrm{Yu}$ Y, Correll PH, Vanden Heuvel JP. Conjugated linoleic acid decreases production of pro-inflammatory products in macrophages: evidence for a PPAR gamma-dependent mechanism. Biochim Biophys Acta. 2002 Apr 15;1581(3):89-99.

68. Renz H, Gong JH, Schmidt A, Nain M, Gemsa D. Release of tumor necrosis factor-alpha from macrophages. Enhancement and suppression are dose- 
dependently regulated by prostaglandin E2 and cyclic nucleotides. J Immunol. 1988 Oct 1;141(7):2388-93.

69. Scales WE, Chensue SW, Otterness I, Kunkel SL. Regulation of monokine gene expression: prostaglandin E2 suppresses tumor necrosis factor but not interleukin-1 alpha or beta-mRNA and cell-associated bioactivity. J Leukoc Biol. 1989 May;45(5):416-21.

70. Clifton P. Dietary fatty acids and inflammation. Nutr Diet. 2009 Mar;66(1):7-11.

71. Lee JY, Sohn KH, Rhee SH, Hwang D. Saturated fatty acids, but not unsaturated fatty acids, induce the expression of cyclooxygenase-2 mediated through Toll-like receptor 4. J Biol Chem. 2001 May 18;276(20):16683-9.

72. Wallace FA, Miles EA, Calder PC. Activation state alters the effect of dietary fatty acids on pro-inflammatory mediator production by murine macrophages. Cytokine. 2000 Sep;12(9):1374-9.

73. Braddock M, Quinn A, Canvin J. Therapeutic potential of targeting IL-1 and IL18 in inflammation. Expert Opin Biol Ther. 2004 Jun;4(6):847-60.

74. Bird S, Zou J, Wang TH, Munday B, Cunningham C, Secombes CJ. Evolution of interleukin-1 beta. Cytokine Growth F R. 2002 Dec;13(6):483-502.

75. Haversen L, Danielsson KN, Fogelstrand L, Wiklund O. Induction of proinflammatory cytokines by long-chain saturated fatty acids in human macrophages. Atherosclerosis. 2009 Feb;202(2):382-93.

76. Medzhitov R. Recognition of microorganisms and activation of the immune response. Nature. 2007 Oct 18;449(7164):819-26.

77. Assier E, Boissier MC, Dayer JM. Interleukin-6: from identification of the cytokine to development of targeted treatments. Joint Bone Spine. 2010 Dec;77(6):532-6.

78. Rose-John S, Scheller J, Elson G, Jones SA. Interleukin-6 biology is coordinated by membrane-bound and soluble receptors: role in inflammation and cancer. J Leukoc Biol. 2006 Aug;80(2):227-36.

79. Weldon SM, Mullen AC, Loscher CE, Hurley LA, Roche HM. Docosahexaenoic acid induces an anti-inflammatory profile in lipopolysaccharide- 
stimulated human THP-1 macrophages more effectively than eicosapentaenoic acid. J Nutr Biochem. 2007 Apr;18(4):250-8.

80. Mullen A, Loscher CE, Roche HM. Anti-inflammatory effects of EPA and DHA are dependent upon time and dose-response elements associated with LPS stimulation in THP-1-derived macrophages. J Nutr Biochem. 2010 May;21(5):444-50.

81. Bonilla DL, Ly LH, Fan YY, Chapkin RS, McMurray DN. Incorporation of a dietary omega 3 fatty acid impairs murine macrophage responses to Mycobacterium tuberculosis. PLoS One. 2010;5(5):e10878.

82. Shi Y, Pestka JJ. Mechanisms for suppression of interleukin-6 expression in peritoneal macrophages from docosahexaenoic acid-fed mice. J Nutr Biochem. 2009 May;20(5):358-68.

83. Jia Q, Zhou HR, Shi Y, Pestka JJ. Docosahexaenoic acid consumption inhibits deoxynivalenol-induced CREB/ATF1 activation and IL-6 gene transcription in mouse macrophages. J Nutr. 2006 Feb;136(2):366-72.

84. Gouwy M, Struyf S, Proost P, Van Damme J. Synergy in cytokine and chemokine networks amplifies the inflammatory response. Cytokine Growth Factor Rev. 2005 Dec;16(6):561-80.

85. Olson TS, Ley K. Chemokines and chemokine receptors in leukocyte trafficking. Am J Physiol Regul Integr Comp Physiol. 2002 Jul;283(1):R7-28.

86. Salanga CL, Handel TM. Chemokine oligomerization and interactions with receptors and glycosaminoglycans: the role of structural dynamics in function. Exp Cell Res. 2011 Mar 10;317(5):590-601.

87. Pereira LM, Hatanaka E, Martins EF, Oliveira F, Liberti EA, Farsky SH, et al. Effect of oleic and linoleic acids on the inflammatory phase of wound healing in rats. Cell Biochem Funct. 2008 Mar-Apr;26(2):197-204.

88. Laine PS, Schwartz EA, Wang Y, Zhang WY, Karnik SK, Musi N, et al. Palmitic acid induces IP-10 expression in human macrophages via NF-kappaB activation. Biochem Biophys Res Commun. 2007 Jun 22;358(1):150-5.

89. Tonnesen MG, Feng X, Clark RA. Angiogenesis in wound healing. J Investig Dermatol Symp Proc. 2000 Dec;5(1):40-6. 
90. Hoeben A, Landuyt B, Highley MS, Wildiers H, Van Oosterom AT, De Bruijn EA. Vascular endothelial growth factor and angiogenesis. Pharmacol Rev. 2004 Dec;56(4):549-80.

91. Toborek M, Lee YW, Garrido R, Kaiser S, Hennig B. Unsaturated fatty acids selectively induce an inflammatory environment in human endothelial cells. Am J Clin Nutr. 2002 Jan;75(1):119-25.

92. Maziere C, Conte MA, Degonville J, Ali D, Maziere JC. Cellular enrichment with polyunsaturated fatty acids induces an oxidative stress and activates the transcription factors AP1 and NFkappaB. Biochem Biophys Res Commun. 1999 Nov;265(1):116-22.

93. Chang CS, Sun HL, Lii CK, Chen HW, Chen PY, Liu KL. Gamma-linolenic acid inhibits inflammatory responses by regulating NF-kappaB and AP-1 activation in lipopolysaccharide-induced RAW 264.7 macrophages. Inflammation. 2010 Feb;33(1):46-57.

94. Zhao G, Etherton TD, Martin KR, Vanden Heuvel JP, Gillies PJ, West SG, et al. Anti-inflammatory effects of polyunsaturated fatty acids in THP-1 cells. Biochem Biophys Res Commun. 2005 Oct 28;336(3):909-17.

95. Calder PC, Yaqoob P, Thies F, Wallace FA, Miles EA. Fatty acids and lymphocyte functions. Br J Nutr. 2002 Jan;87 (Suppl 1):S31-48.

96. Oller do Nascimento CM, Ribeiro EB, Oyama LM. Metabolism and secretory function of white adipose tissue: effect of dietary fat. An Acad Bras Cienc. 2009 Sep;81(3):453-66.

97. Uusitupa M, Schwab U, Makimattila S, Karhapaa P, Sarkkinen E, Maliranta H, et al. Effects of two high-fat diets with different fatty acid compositions on glucose and lipid metabolism in healthy young women. Am J Clin Nutr. 1994 Jun;59(6):13106.

98. $\mathrm{Mu} \mathrm{H}$, Hoy CE. The digestion of dietary triacylglycerols. Prog Lipid Res. 2004 Mar;43(2):105-33.

99. Wang $\mathrm{H}$, Eckel $\mathrm{RH}$. Lipoprotein lipase: from gene to obesity. Am J Physiol Endocrinol Metab. 2009 Aug;297(2):E271-88.

100. Cooper AD. Hepatic uptake of chylomicron remnants. J Lipid Res. 1997 Nov;38(11):2173-92. 
101. Canbay A, Bechmann L, Gerken G. Lipid metabolism in the liver. Z Gastroenterol. 2007 Jan;45(1):35-41.

102. Sundaram M, Yao Z. Recent progress in understanding protein and lipid factors affecting hepatic VLDL assembly and secretion. Nutr Metab (Lond). 2010;7:35.

103. Nguyen P, Leray V, Diez M, Serisier S, Le Bloc'h J, Siliart B, et al. Liver lipid metabolism. J Anim Physiol Anim Nutr (Berl). 2008 Jun;92(3):272-83.

104. Leyton J, Drury PJ, Crawford MA. Differential oxidation of saturated and unsaturated fatty acids in vivo in the rat. Br J Nutr. 1987 May;57(3):383-93.

105. Fremont L, Gozzelino MT. Dietary sunflower oil reduces plasma and liver triacylglycerols in fasting rats and is associated with decreased liver microsomal phosphatidate phosphohydrolase activity. Lipids. 1996 Aug;31(8):871-8. 